\title{
KULTURA BIBLIOGRAFICZNA LUBELSKIEGO ŚRODOWISKA NAUKOWEGO OD KOŃCA XIX WIEKU DO ROKU 2016
}

Kultury bibliograficznej nie nabywa się od razu. Kształtuje się ona wraz z rozwojem naukowym uczonego, przyrostem jego wiedzy i doświadczenia. Jest czymś w rodzaju humanistycznego doświadczenia ogólnego. Mając wykształconą kulturę bibliograficzną w pełni dostrzega się i docenia dokumentację bibliograficzną jako podstawę rozwoju badań naukowych. Kultura bibliograficzna pozwala także znaleźć nić porozumienia między uczonymi reprezentującymi skrajnie różne dziedziny. Umiejętność krzewienia świadomości bibliograficznej i nieustanne poszukiwanie nowych obszarów bibliograficznych to kolejna pochodna omawianego pojęcia.

Na kanon kultury bibliograficznej składa się jej tradycja, czyli zarówno wcześniejsza twórczość bibliograficzna, jak i cały dorobek z nią związany, ludzie, instytucje i ich osiągnięcia przyczyniające się do propagowania bibliografii. Błędem byłoby jednak myśleć o kulturze bibliograficznej tylko w kontekście jej trwałych osiągnięć w postaci prac bibliograficznych. Twórcami kultury bibliograficznej są animatorzy, inspiratorzy i wykonawcy przedsięwzięć bibliograficznych, a żywot swój zawdzięcza ona odbiorcom, którzy rozumieją i doceniają wartość działalności bibliograficznej, korzystają z jej wytworów i to oni współdecydują o poziomie tej kultury i jej rozwoju.

Pojęciem „lubelskie środowisko naukowe” objęto pracowników naukowych związanych zawodowo z lubelskimi wyższymi uczelniami. Spojrzano na nich

*Alicja Matczuk - dr hab. bibliologii i informatologi; adiunkt w Instytucie Informacji Naukowej i Bibliotekoznawstwa, Uniwersytet Marii Curie-Skłodowskiej w Lublinie; e-mail: alicjamatczuk@tlen.pl

ORCID 0000-0001-7225-3996

**Artur Znajomski - dr hab. bibliologii i informatologi; adiunkt w Instytucie Informacji Naukowej i Bibliotekoznawstwa, Uniwersytet Marii Curie-Skłodowskiej w Lublinie; e-mail: aznajomski@o2.pl

ORCID 0000-0002-9895-5184 
przez pryzmat ich osiągnięć i dokonań w dziedzinie bibliografii. Nikt dotąd nie napisał choćby szkicu o swoistości pisarstwa bibliograficznego lubelskich uczonych, a przecież odkrywali i dokumentowali oni nowe, nieznane obszary piśmiennictwa naukowego i regionalnego, inicjowali przedsięwzięcia bibliograficzne, rozbudzali zainteresowania tą czy inną przestrzenią badawczą. Dzięki ich wysiłkom powstało szereg bibliografii różnego typu, tak o charakterze retrospektywnym (zwykle w dużych ciągach czasowych), jak i bieżącym. Interesować nas będą bibliografie wydane w postaci druków samoistnych zwartych, wydawnictw ciągłych, artykułów z czasopism oraz rozpraw z prac zbiorowych.

Na obraz kultury bibliograficznej lubelskiego środowiska uniwersyteckiego składa się szereg elementów. $Z$ całą pewnością jednak w jej kształtowaniu istotną rolę odegrali wybitni uczeni bibliografowie, którzy związali się z Lublinem. W praktyce czasem jedna i ta sama osoba ustalała zasadniczy klimat bibliograficzny. Obserwując działalność bibliograficzną tych osób, analizując ich twórczość i inicjatywy w dziedzinie bibliografii, obserwujemy tym samym przemiany w obrazie bibliograficznym, jakie dokonywały się w podejmowanej działalności bibliograficznej. Chcąc zatem mówić o kulturze bibliograficznej lubelskiego środowiska naukowego, trzeba wspomnieć w pierwszym rzędzie właśnie o ludziach, którzy przyczynili się do rozbudzenia zainteresowań bibliograficznych w Lublinie.

Dobre tradycje pracy bibliograficznej zapoczątkowali, zajmujący w swoim czasie poważną pozycję w polskim świecie naukowym, o szerokich zainteresowaniach Hieronim Łopaciński oraz zasłużony badacz dziejów regionu lubelskiego Henryk Wiercieński. Należeli oni do nowej już generacji badaczy prowincjonalnych, wykorzystujących osiągnięcia szkół i metod pozytywistycznych poznane w czasie studiów w Warszawie. Z okresu studiów wynieśli także zamiłowanie do bibliografii.

Jednym z pierwszych uczonych lubelskich, który przejawiał zainteresowanie bibliografią był H. Wiercieński. Studiował w Kijowie i w warszawskiej Szkole Głównej, skąd poszedł do powstania styczniowego. Po powrocie z zsyłki z Syberii, rozwinął żywą działalność publicystyczną i naukową, zwłaszcza w zakresie ekonomii, demografii, etnografii, archeologii i historii. Rozpoczął także publiczną działalność bibliograficzną. Jedną z jej form było dostarczanie społeczeństwu bieżącej informacji o nowo wychodzących książkach. Recenzje krajowych i zagranicznych nowości wydawniczych, w tym także prac bibliograficznych, ogłaszał m.in. w „Gazecie Polskiej”, „Gazecie Warszawskiej” i „Niwie”.

Jednak trwałą sławę i uznanie w dziedzinie bibliografii polskiej zdobył dopiero H. Łopaciński. Przybył do Lublina w 1884 r. jako absolwent Wydziału Historyczno-Filologicznego Uniwersytetu Warszawskiego, by nauczać w miejscowym liceum rządowym łaciny i greki. Filolog klasyczny z wykształcenia, dzięki wszechstronnym uzdolnieniom i szczerej pasji badawczej rozwinął na wielką skalę badania i poszukiwania naukowe $\mathrm{w}$ wielu dziedzinach. Pasjonował się także bibliografią ${ }^{1}$. W oczach współczesnych uchodził za autorytet w tej dziedzinie. $\mathrm{Na}$

${ }^{1}$ M. Krzywicka, A. Matczuk, Bibliografia w kręgu zainteresowań Hieronima Łopacińskiego, w: Hieronim Łopaciński epoka, ludzie, region. Materiaty z konferencji naukowej. Lublin, 19-20 września 2006, red. Z. Bieleń, Lublin 2006, s. 127-142. 
jego ręce kierowane były liczne kwerendy naukowe i bibliograficzne, wymagające nieraz żmudnych heurystycznych poszukiwań. Utrzymywał on bliskie kontakty z wieloma uczonymi-bibliografami m.in. Samuelem Dicksteinem, Adamem A. Kryńskim, Szczęsnym Jastrzębowskim, Janem Przyborowskim, a szczególnie zaprzyjaźnił się z Teodorem Wierzbowskim, któremu dostarczał materiałów do jego Bibliographia Polonica XV ac XVI ss., przeszukując w tym celu księgozbiory bibliotek lubelskich. Prawdziwego bibliografa można poznać w zestawieniach bibliograficznych. Był on autorem rozprawki Wydawnictwa periodyczne w Lublinie, ogłoszonej w „Kalendarzu Lubelskim” na rok 1891, zawierającej zestawienie wydawnictw periodycznych (kalendarzy, sprawozdań, protokołów i czasopism) ukazujących się w Lublinie, od XVII do lat 80. XIX wieku. Stanowiła ona pierwsze opracowanie bibliograficzne dotyczące regionu lubelskiego. W swoim dorobku bibliograficznym miał pracę o Najdawniejszych stownikach polskich drukowanych (1893), zawierającą wykaz słowników XVI-wiecznych i ich bardzo liczne wydania oraz bibliografie osobowe podmiotowe: Lucjana Malinowskiego, Jana Karłowicza i Feliksa Kółkowskiego. Bardzo kompetentnie napisał hasło „Katalog" do Wielkiej powszechnej encyklopedii ilustrowanej, w którym sporo miejsca poświęcił „katalogom bibliograficznym”, podejmując przy tym próbę sprecyzowania pojęć i terminów, jak i pewne odniesienia do typologii bibliografii. Zważywszy na znikome zainteresowanie teorią bibliografii w tym czasie, uwagi i przemyślenia $H$. Łopacińskiego były tym cenniejsze i wyznaczyły mu ważne miejsce w historii poglądów na bibliografię. Pokazał on, że na prowincji pozbawionej biblioteki naukowej, można zajmować się problematyką bibliograficzną $\mathrm{i}$ to $\mathrm{z}$ niemałym powodzeniem, z wynikami, które zwróciły na siebie uwagę ówczesnego polskiego środowiska naukowego. Jego działalność bibliograficzna przekraczała ramy regionu lubelskiego, stając się trwałym dorobkiem bibliografii ogólnonarodowej.

Zakładając, że środowiska naukowe tworzą ludzie i instytucje działające w określonych warunkach, można przyjąć, że lubelskie środowisko naukowe ukształtowało się po 1918 r., w odrodzonej Ojczyźnie, z chwilą powstania Uniwersytetu Lubelskiego (od 1928 r. Katolickiego Uniwersytetu Lubelskiego), powołania Archiwum Państwowego oraz w związku z powstaniem towarzystw naukowych. Większość pracowników naukowych przybyłych do Lublina wywodziła się z Lwowa, Krakowa i Poznania. Dla nich było rzeczą oczywistą, że zarówno z racji pobytu na ziemi lubelskiej, jak i potrzeb naukowych, winni się w jakimś stopniu zająć problematyką regionu lubelskiego w zakresie uprawianej przez siebie dyscypliny.

Mówiąc o kulturze bibliograficznej lubelskiego środowiska naukowego w okresie międzywojennym nie sposób nie wspomnieć, choćby w kilku słowach, o dokonaniach bibliograficznych i stosunku do bibliografii ks. Idziego Radziszewskiego, współtwórcy i pierwszego rektora KUL. Mało znany lub znany w niewielkim stopniu jest fakt, że trwałą zasługą ks. I. Radziszewskiego w dziejach bibliografii polskiej było podjęcie pierwszej próby zorganizowania polskiej bibliografii 
filozoficznej². Ukazywała się ona w latach 1905-1906 w nowatorskim układzie klasyfikacji dziesiętnej Deweya. On również pierwszy w Polsce podał wiadomość o tym systemie. Zainicjowana przez ks. I. Radziszewskiego bibliografia spotkała się z dużym zainteresowaniem i pozytywnym przyjęciem. Niestety ukazały się tylko trzy zeszyty wydawnictwa z powodu braku środków finansowych. Do pracy bibliograficznej ks. I. Radziszewski nigdy potem nie wrócił.

Będąc już rektorem Uniwersytetu Lubelskiego ks. I. Radziszewski dał świadectwo, że pracę naukową w dziedzinie bibliografii w pełni doceniał oraz darzył dużym szacunkiem. Dowodem uznania i wysokiej oceny dorobku naukowego Franciszka Gawełka, nauczyciela gimnazjalnego z tytułem doktora, znanego w środowisku naukowym głównie z racji opracowania retrospektywnej bibliografii etnograficznej, było powierzenie mu przez ks. I. Radziszewskiego w 1919 r. wykładów etnografii na uniwersytecie ${ }^{3}$. Z przyjazdem do Lublina F. Gawełek wiązał wiele planów, ale na przeszkodzie stanęła jego nieoczekiwana i nagła śmierć.

Nowy rozdział w życiu bibliograficznym miasta rozpoczął się z chwilą przyjazdu do Lublina w 1920 r. Wiktora Hahna, profesora historii literatury polskiej Uniwersytetu Jana Kazimierza w Lwowie, a zarazem znawcy problematyki bibliograficznej ${ }^{4}$. Należał on do nielicznych uczonych polskich posiadających habilitację z bibliografii i bibliotekarstwa oraz legitymował się imponującym dorobkiem bibliograficznym. W. Hahn związał się na cały okres dwudziestolecia nie tylko z Uniwersytetem Lubelskim, ale także z zaczynającym coraz mocniej pulsować życiem umysłowym Lublina i regionu. Jako bibliograf wystąpił na początku swej działalności w Uniwersytecie z Bibliografia bibliografii polskiej (1921). Mimo iż cały czas mieszkał W. Hahn we Lwowie, czuł się bardzo blisko związany z lubelskim środowiskiem naukowym. Jak pisał Feliks Araszkiewicz „Był on w ciągu tego czasu tyle lwowianinem, co lublinianinem"s.

W. Hahn nie na darmo uchodził za jednego z najbieglejszych i najpracowitszych bibliografów w tym czasie. Wraz z przybyciem do Lublina, z właściwą sobie energią rozwinął aktywność bibliograficzną, starając się stworzyć przyjazny klimat i zachęcić środowisko naukowe do podejmowania prac dokumentacyjnych ${ }^{6}$. Jego działalność bibliograficzną czuło się w Lublinie bardzo wydatnie. Dyktowały ją bieżące potrzeby nauki, bądź okoliczności rocznicowe. Już w $1922 \mathrm{r}$. na zebraniu naukowym Lubelskiego Oddziału Towarzystwa Literackiego im. Adama Mickiewicza rzucił myśl zespołowego opracowania retrospektywnej bibliografii Lublina jako podstawy rozwoju badań regionalnych. Początkowo prace nad przedsięwzięciem przebiegały wartko, ale z czasem zapał i zaangażowanie wygasły. Nie opuściły one tyko pomysłodawcę, który chciał nade wszystko

${ }^{2}$ A. Matczuk, Lublin i Lubelszczyzna w życiu i twórczości wybitnych polskich bibliografów, „Bibliotekarz Lubelski”, 47 (2004), s. 108-110.

${ }^{3}$ Tamże, s. 110-111.

${ }^{4}$ A. Znajomski, Wiktor Hahn jako bibliograf lubelski, w: Lublin a książka, red. A. Krawczyk, E. Józefowicz-Wisińska, Lublin 2004, s. 609-624.

${ }^{5}$ F. Araszkiewicz, Zastugi Wiktora Hahna dla środowiska naukowego. (Przemówienie Feliksa Araszkiewicza), „Zeszyty Naukowe KUL”, 3 (1960) nr 1, s. 159.

${ }^{6}$ Znajomski, Wiktor Hahn, s. 610. 
przygotować dzieło i głównie temu zadaniu podporządkował kolejne lata życia. Niestety bibliografia nie ukazała się drukiem i do dziś spoczywa w formie kartoteki. Zaznaczył on swój udział także w obchodach staszicowskich, przygotowując m.in. bibliografię o Stanisławie Staszicu do księgi zbiorowej, wydanej w 1928 r. Podjął się również opracowywania bieżącej bibliografii województwa lubelskiego do „Regionu Lubelskiego” organu Towarzystwa Przyjaciół Nauk. Ogłosił wszakże zestawienie tylko za rok 1927, ponieważ czasopismo zostało zawieszone. Autor gromadził materiały z tego zakresu i później, nie mając okazji i możliwości ogłoszenia ich drukiem.

Uznać trzeba, że pozyskanie do lubelskiego środowiska naukowego W. Hahna okazało się dobrym nabytkiem. Nie będzie chyba przesady w stwierdzeniu, że przyczynił się on w poważnym stopniu do podniesienie kultury i świadomości bibliograficznej wśród uczonych lubelskich. O wartości jego dziedzictwa stanowiły trzy elementy: uświadomienie potrzeby prowadzenia dokumentacji piśmiennictwa regionalnego jako podstawy rozwoju badań regionalnych, zainicjowanie prac nad retrospektywną bibliografią Lublina, zapoczątkowanie bieżącej rejestracji piśmiennictwa regionalnego. Swoją pracą bibliograficzną na rzecz regionu dał świadectwo swego związku ze środowiskiem naukowym w Lublinie. Przekaz bibliograficzny W. Hahna znalazł kontynuatorów. Ksiądz Ludwik Zalewski i F. Araszkiewicz podjęli prace w dziedzinie bibliografii regionalnej literackiej ${ }^{7}$, natomiast Leon Białkowski - bieżącej bibliografii historycznej ${ }^{8}$. Warto nadmienić, iż inicjatywa uczonych lubelskich należała do jednych z pierwszych w tym zakresie w Polsce.

W tym miejscu należy także wspomnieć o bibliografii satyrycznej zrodzonej w kręgu uczonych bibliofilów, wydanej w 1931 r. w Lublinie pt. Nowości lubelskie. Katalog regionalny najwybitniejszych autorów miejscowych ${ }^{9}$. Dziełko to, ogłoszone w formacie karty pocztowej, zawierało opisy bibliograficzne fikcyjnych książek przypisanych różnym osobom ze środowiska lubelskiego. Twórcami tej zabawy byli profesorowie KUL (Henryk Życzyński, Zygmunt Kukulski, Zygmunt Tołwiński) oraz szkół średnich (ks. L. Zalewski, F. Araszkiewicz), a także literat Józef Czechowicz. Celem publikacji było ukazanie słabostek znajomych z kręgu wydawców, naukowców, księży i literatów lubelskich, poprzez dowcipne sformułowanie tytułów i tematyki domniemanych utworów. Znakomity dowcip tych tytułów, w pełni zrozumiały dla ówczesnego czytelnika, jest dzisiaj znacznie mniej czytelny, nieco obcy, choć w wielu przypadkach nadal może bawić. Długo nie milkły echa wydania książeczki. Jeszcze w 1932 r. prasa lokalna donosiła, że

${ }^{7}$ W 1939 r. ukazała się Antologia współczesnych poetów lubelskich, wydana przez ks. L. Zalewskiego, zawierająca życiorysy i bibliografię poetów lubelskich oraz zarys informacyjno-bibliograficzny Ruch literacki w Lubelszczyźnie 1918-1938. Cyfry, daty, nazwiska, tytuły pióra F. Araszkiewicza. Zob. A. Matczuk, Rozwój bibliografii ziemi lubelskiej, w: Lublin a książka, s. 536-537.

${ }^{8}$ L. Białkowski, Produkcja historyczna regionu lubelskiego w r. 1930-1931, „Kwartalnik Historyczny", 46 (1932) s. 171-173. Zob. Matczuk, Rozwój bibliografii, s. 537.

${ }^{9}$ A. Matczuk, ,Nowości lubelskie” - przyczynek do dziejów humoru bibliograficznego w Polsce, „Folia Bibliologica”, 52 (2010), s. 9-26. 
(...) narobiły wiele wrzawy i pobudziły niejednego do wesołości, a gdyby nawet do irytacji, to i tak podniosły znacznie poziom zdrowia miasta Lublina, jako, że dobry żart tynfa wart. Wiadomo, że nie wszyscy poznali się na żarcie i wiele osób poczuło się dotkniętych i obrażonych ${ }^{10}$.

Dwudziestolecie międzywojenne przekazało okresowi powojennemu skromny, ale pionierski i liczący się dorobek bibliograficzny, a nade wszystko rozbudzone i żywe zainteresowania problematyką bibliograficzną o charakterze regionalnym.

Po drugiej wojnie światowej lubelskie środowisko uniwersyteckie zostało znacznie wzmocnione, albowiem obok KUL, w 1944 r. rozpoczął działalność Uniwersytet Marii Curie-Skłodowskiej. Kadrę naukową stanowili przede wszystkim pracownicy naukowi przesiedleni z Kresów Wschodnich (Lwów, Wilno). Z lubelskimi uniwersytetami związali się także uczeni wywodzący się z innych przedwojennych ośrodków naukowych (Kraków, Poznań). Większość z nich pozostała w Lublinie do końca życia.

Wśród przybyłych do Lublina znalazły się uznane autorytety w dziedzinie bibliografii, uczeni parający się pracą bibliograficzną bądź wywodzący się ze środowisk naukowych, darzących wielką estymą działalność bibliograficzną. Do grona tego należeli m.in. Andrzej Wojtkowski, Leon Kaczmarek, Andrzej Waksmundzki oraz Józef Reutt. Nie sposób przecenić znaczenia ich wytrwałej i przemyślanej działalności bibliograficznej na rzecz nauki polskiej lub regionu lubelskiego, a następnie rozwoju kultury bibliograficznej wśród studentów i wychowanków uniwersytetów lubelskich. Zapewniali im odpowiednią edukację bibliograficzną, wprowadzając w tajniki pracy bibliograficznej, której pozytywne rezultaty w postaci aktywności bibliograficznej młodego pokolenia pracowników naukowych, postrzegamy tak dobrze w następnych dziesięcioleciach. Widomą oznaką były inicjowane i podejmowane przez nich prace bibliograficzne.

Pierwsza powojenna dekada nie była pomyślna dla aktywności bibliograficznej lubelskiego środowiska naukowego. Zmiany metodologiczno-ideologiczne i organizacyjne w nauce polskiej, wymuszone uwarunkowania polityczne i cenzura odbiły się niekorzystnie na podejmowaniu i inicjowaniu prac bibliograficznych. Ograniczano swobodę działalności bibliograficznej planami naukowymi i wydawniczymi. Bez względu na potrzeby i uzasadnienia naukowe i praktyczne niemożliwe było opracowywanie i publikowanie bibliografii z różnych względów niewygodnych w danym okresie dla systemu władzy, jak np. dziedziny wiedzy, tematu, a także autora.

Klasycznym tego przykładem była retrospektywna bibliografia historyczna województwa lubelskiego opracowana przez historyka, bibliografa i bibliotekarza A. Wojtkowskiego, związanego przed wojną ze środowiskiem poznańskim ${ }^{11}$. Do Lublina przyjechał w 1944 r. i związał się z Katolickim Uniwersytetem Lubelskim, obejmując katedrę historii kultury polskiej. Początkowo zamierzał wrócić w

${ }^{10}$ Tamże, s. 18-19.

${ }^{11} \mathrm{O}$ genezie i losach przedsięwzięcia zob. A. Matczuk, Wprowadzenie do bibliografii, w: A. Wojtkowski, Bibliografia historii województwa lubelskiego, wydały M. Juda, A. Matczuk przy współpracy A. Znajomskiego, Lublin 2000, s. 21-30. 
rodzinne strony, gdzie zostawił warsztat naukowy, jednak ostatecznie pozostał w Lublinie, wiążąc się z nim do końca życia. A. Wojtkowski przybywając do Lublina, uchodził za autorytet $\mathrm{w}$ dziedzinie bibliografii historycznej. Uznanie to zdobył dzięki znakomicie przygotowanej retrospektywnej bibliografii historii Wielkopolski, górującej pod względem metodycznym wśród bibliografii regionalnych okresu międzywojennego. A. Wojtkowski wszedł w nowe, inne środowisko historyczne, co zaważyć musiało także na kierunku jego studiów, także bibliograficznych. Jako znawcy bibliografii i zarazem aktywnemu członkowi lubelskiego oddziału Polskiego Towarzystwa Historycznego wypadało zaangażować się w „zagospodarowanie bibliograficzne” regionu lubelskiego, który pod tym względem odznaczał się w skali kraju dość dużym zaniedbaniem. $Z$ poczucia obowiąz$\mathrm{ku}$, ale też z zamiłowania do bibliografii i duszą historyka przystąpił „od zaraz” (1947) do opracowywania bibliografii historii województwa lubelskiego. Mimo, że perspektywa wydania dzieła w latach 50 . była wątpliwa, z powodu negatywnego podejścia władz do regionalizmu, A. Wojtkowski kontynuował pracę nad bibliografią, przy współudziale swoich seminarzystów i studentów kółka historycznego KUL. Dzieło było gotowe w 1968 r. i miało ukazać się w ramach akcji wydawniczej oddziału lubelskiego PTH. Do druku jednak nie doszło. Na skutek negatywnej recenzji wydawniczej pióra jednego z lubelskich historyków, która m.in. zarzucała stosowanie przedwojennych wytycznych metodologicznych, A. Wojtkowski wstrzymał zabiegi o publikację dzieła. Nie zarzucił jednak całkowicie myśli o druku bibliografii i do końca życia powracał do niej, wprowadzając liczne uzupełnienia i poprawki. Po śmierci A. Wojtkowskiego (1975) praca poszła w zapomnienie. Do 1989 r. nie podjęto żadnych działań zmierzających do wydania bibliografii, mimo licznych apeli historyków, którzy dotkliwie odczuwali jej brak i dopominali się druku pracy.

Szacunek i uznanie dla autorytetu A. Wojtkowskiego w dziedzinie bibliografii oraz sama możliwość kontaktu z nim były niewątpliwie ważnym czynnikiem w kształtowaniu kultury bibliograficznej lubelskiego środowiska historycznego. Miał on poważny udział w rozbudzaniu i rozwijaniu zainteresowań bibliograficznych swoich uczniów na wykładach, ćwiczeniach i seminariach uniwersyteckich. Niektórzy z nich, podejmując później działalność naukową na uniwersytetach lubelskich, w naturalny sposób kontynuowali jego zainteresowania bibliograficzne. Do grona tego należeli m.in. Jerzy Starnawski, Henryk Zins, Józef Szymański, Jan Ziółek oraz Maria Jasińska, późniejsza żona A. Wojtkowskiego.

Najwcześniej, bo już na początku lat 50. XX w., pracę naukową w dziedzinie bibliografii rozpoczął J. Starnawski, absolwent polonistyki KUL, następnie pracownik naukowy uniwersytetu w latach 1950-1964. Zaliczał on A. Wojtkowskiego do ważkich i znaczących postaci, które spotkał w trakcie uniwersyteckiej edukacji ${ }^{12}$. Dzięki niemu bibliografia stała się jedną z dwóch domen, obok historii literatury, w twórczości i działalności naukowej J. Starnawskiego. Ogłosił on

${ }^{12}$ E. Hadrian, Profesor Jerzy Starnawski (1922-2012) - historyk i badacz literatury polskiej, neolatynista, bibliograf, pedagog, edytor, erudyta, „Bibliotekarz Lubelski”, 55 (2012) s. 21. 
m.in. bibliografię literacką Lubelszczyzny za lata $1944-1957^{13}$, stanowiącą kontynuację prac ks. L. Zalewskiego i F. Araszkiewicz oraz bibliografię H. Łopacińskiego $^{14}$. Nie poprzestał jednak na tym i rozszerzył przestrzeń badawczą o zagadnienia teorii i metodyki bibliograficznej, niezwykle ważne ze względu na znikome zainteresowanie tymi kwestiami w tym czasie. Owocem jego zainteresowań był Warsztat bibliograficzny historyka literatury polskiej (1957) ${ }^{15}$, będący podręcznikiem przeznaczonym dla studentów filologii polskiej, a pośrednio - dla ogółu polonistów. Praca dostarczała informacji o bibliografiach, uczyła posługiwania się nimi, a wreszcie starała się pomóc $\mathrm{w}$ sporządzaniu zestawień piśmiennictwa, stanowiących pierwszy etap pracy naukowej. Była ona niesłychanie ważna z punktu widzenia kształtowania i rozwoju świadomości bibliograficznej studentów, dawała interesujący przykład znajomości bibliografii, potrzeby jej posiadania i odrębności kulturowej oraz wskazywała możliwości jej wykorzystania w pracy badawczej.

Nieprzychylna i krytyczna postawa ówczesnych władz do psychologii, uważanej za naukę burżuazyjną, nie pozwoliła na rozwinięcie potencjału bibliograficznego J. Reutta oraz przygotowanie retrospektywnej polskiej bibliografii psychologicznej. Uczony ten, w 1954 r. wskutek zamierzonej likwidacji studiów psychologicznych w Uniwersytecie Poznańskim, opuścił tę uczelnię i rozpoczął pracę w charakterze profesora i kierownika Katedry Psychologii KUL, a po trzech lat przeszedł do UMCS. Jeszcze w okresie poznańskim, dokonując analizy dzieł naukowych psychologów polskich w aspekcie historycznym J. Reutt dostrzegał konieczność zestawienia polskiej bibliografii psychologicznej ${ }^{16}$. Praca ta rozpoczęta pod kierunkiem Stefana Błachowskiego, mistrza J. Reutta, została przerwana $\mathrm{w}$ wyniku przemian metodologiczno-ideologicznych $\mathrm{w}$ nauce polskiej ${ }^{17}$. Interesujące uwagi na temat bibliografii J. Reutt opublikował w 1949/1950 r. w „Ruchu Filozoficznym”. Przez jakiś czas kontynuował on pracę nad bibliografią, ale ostatecznie jej zaniechał, mając świadomość, że nie ujrzy ona nigdy światła druku. Prawdopodobnie $\mathrm{z}$ tego też powodu nie powrócił do sprawy bibliografii w okresie lubelskim.

Po roku 1956 warunki rozwoju ruchu bibliograficznego uległy poprawie. Wydatny rozwój bibliografistyki w lubelskim środowisku naukowym miał też swoje uwarunkowania. Składały się na nie: widoczna poprawa w zakresie rozwoju naukowego środowiska uniwersyteckiego, zwiększenie kadry pracowników naukowych, zmiany w zakresie organizacji szkół wyższych w Lublinie: z wydziałów

${ }^{13}$ J. Starnawski, Bibliografia literacka Lubelszczyzny 1944-1954, „Kamena”, (1954) nr 1-3, s. 148-154; Bibliografia literacka Lubelszczyzny 22 VII 1954-31 XII 1957, [Lublin 1957], 15 s.; „Kamena” (1957), dodat. do nr 22-23, s. 1-16. Zob. Matczuk, Rozwój bibliografii, s. 538-539.

${ }^{14}$ J. Starnawski, Bibliografia Hieronima Lopacińskiego, w: Hieronim Łopaciński i Biblioteka Jego imienia w Lublinie 1907-1957, red. F. Araszkiewicz, Lublin 1967, s. 89-126.

${ }^{15}$ J. Starnawski, Warsztat bibliograficzny historyka literatury polskiej, Lublin 1957.

${ }^{16}$ W. Bobrowska-Nowak, Profesor Józef Reutt (1907-1972), „Psychologia Wychowawcza”, 16 (1973) s. 530.

${ }^{17}$ A. Matczuk, Polskie bibliografie nauk humanistycznych i spolecznych. Historia i metodyka, Lublin 2014, s. 98. 
lekarskiego, weterynaryjnego i rolnego UMCS powstały samodzielne uczelnie - Akademia Medyczna i Wyższa Szkoła Rolnicza. Rozpoczęła także pracę Wieczora Szkoła Inżynierska, z czasem przekształcona w Politechnikę Lubelską.

Twórczość bibliograficzną zaczęło uprawiać obok starszego, również nowe pokolenie pracowników naukowych, wykształcone już po wojnie w UMCS i KUL. W gronie tym spotykamy osoby o głębokim zainteresowaniu problematyką bibliograficzną. Potwierdza to niejedno zestawienie bibliograficzne. Niewielu badaczy zamykało się w ramach jednego typu bibliografii. Częstym natomiast zjawiskiem było uprawianie różnych jej rodzajów.

Działalność bibliograficzna uczonych lubelskich przekraczała nierzadko ramy regionu lubelskiego, stając się trwałym dorobkiem bibliografii ogólnopolskiej $\mathrm{z}$ danej dziedziny wiedzy. Składała się ona w zasadzie $\mathrm{z}$ indywidualnych dokonań badaczy, którzy tworzyli bibliografie związane z własnymi badaniami naukowymi. Autorami bibliografii byli często uczeni starszego pokolenia. Prace ich wyróżniały się metodą, znaczeniem i zakresem materiału.

Dużym przedsięwzięciem bibliograficznym była Polska bibliografia logopedyczna opracowana z inicjatywy językoznawcy i profesora UMCS L. Kaczmarka, założyciela pierwszego w Polsce uniwersyteckiego Zakładu Logopedii. Z Lublinem związał się on w 1954 r., podejmując, już jako docent, pracę na UMCS w charakterze kierownika Katedry Języka Polskiego. Zainteresowania naukowe i bibliograficzne wyniósł ze studiów na Uniwersytecie Poznańskim, gdzie jego mistrzem był Henryk Ułaszyn, znakomity językoznawca i bibliograf. L. Kaczmarek, nazwany dziś „ojcem polskiej logopedii”, swoją ukochaną i z pasją uprawianą dziedzinę obdarzył pierwszą polską bibliografią piśmiennictwa z zakresu logopedii i dyscyplin pogranicznych, od połowy XIX wieku do 1960 r. $^{18}$ Praca została przygotowana przy współudziale Józefa Kani, pracownika Katedry Języka Polskiego i Zdzisława Dobrzańskiego z Biblioteki Głównej UMCS, a wydana w 1965 r. pod patronatem Polskiego Towarzystwa Logopedycznego. Przewidziana była kontynuacja bibliografii, uwzględniająca również tytuły z bogatej literatury poświęcone wymowie XVII, XVIII i pierwszej połowy XIX wieku ${ }^{19}$. Niestety do jej realizacji nie doszło.

Wielka zasługa L. Kaczmarka polegała również na tym, że potrafił rozbudzić zainteresowania bibliograficzne u swoich uczniów. Świadczy o tym fakt, że z grona jego wychowanków (późniejszych pracowników UMCS) działalność bibliograficzną prowadził J. Kania i Jerzy Bartmiński, szczególnie ten ostatni dał się później poznać jako autor i inicjator badań bibliograficznych z zakresu etnolingwistyki.

${ }^{18}$ L. Kaczmarek, Z. Dobrzański, J. Kania, Polska bibliografia logopedyczna, Lublin 1965. Rec.: Z. Br., „Kwartalnik Historii Nauki i Techniki”, 12 (1967) z. 1, s. 181-182; J. Stachyra „Szkoła specjalna” 1967, nr 1, s. 88; W.R. Rzepka „Biuletyn Fonograficzny” 9 (1968), s. 132-135; G.F. Meyer „Zeitschrift fur Phonetik. Sprachwissenschaft und Kommunikationsforschung” 34 (1971) H. 5, s. 445-446.

${ }^{19}$ Z. Br., „Kwartalnik Historii Nauki i Techniki”, s. 182. 
Specjaliście z zakresu chemii fizycznej A. Waksmundzkiemu, twórcy „lubelskiej szkoły chromatografii" ${ }^{20}$, nauka polska zawdzięcza pierwszą polską bibliografię z zakresu chromatografii za lata 1947-197721. Ukazała się ona w trzech częściach chronologicznych, przy czym pierwsza nakładem Lubelskiego Towarzystwa Naukowego, dwie pozostałe już pod patronatem Polskiej Akademii Nauk. Zainteresowania bibliograficzne A. Waksmundzkiego w tej dziedzinie kontynuował Józef Kazimierz Różyło, wydając bibliografię za lata 1978-1982²2.

Powszechnie znane są także prace bibliograficzne Tadeusza Margula z zakresu religioznawstwa powszechnego i bibliografie religioznawców ogłaszane od 1957 roku na łamach „Euhemera"23. Istotne z punktu widzenia dokumentacyjnego było jego opracowanie Międzynarodowa bibliografia religioznawstwa porównawczego w układzie działowym (1984) ${ }^{24}$. Prace te przyczyniły się do tworzenia warsztatu naukowego religioznawstwa w powojennej Polsce.

Spośród innych retrospektywnych bibliografii dziedzinowych na uwagę zasługuje zestawienie z zakresu filozofii za lata 1918-1939², przygotowane przez Lecha Zdybla, pracownika Instytutu Filozofii i Socjologii UMCS.

Dużym przedsięwzięciem bibliograficznym było podjęcie w połowie lat 80 . $\mathrm{XX}$ w. prac nad retrospektywną polską bibliografią nauk pomocniczych historii z inicjatywy J. Szymańskiego, historyka-mediewisty ${ }^{26}$. Realizacją przedsięwzięcia zajęli się pracownicy Zakładu Nauk Pomocniczych Historii i Bibliotekoznawstwa UMCS. Niestety, prace mocno już zaawansowane zostały przerwane z braku funduszy. Choć J. Szymański nie był bibliografem publikującym, to znał się na bibliografii fachowo i doceniał znaczenie tej metody. Swoją kreatywność bibliograficzną rozwinął w następnej dekadzie, występując m.in. z pomysłem przygotowania pełnej dokumentacji dorobku pracowników naukowych UMCS, następnie dorobku pracowników Wydziału Humanistycznego, o czym będzie mowa później.

Inny uczeń A. Wojtkowskiego, H. Zins dał wyraz swoim zainteresowaniom bibliograficznym w recenzjach bibliografii historycznych, zwłaszcza angielskich. Opracował on również Warsztat bibliograficzny historyka brytyjskiego ${ }^{27}$, zawierający wyczerpujące omówienie brytyjskich bibliografii historycznych, mających

${ }^{20}$ J. Rayss, Profesor Andrzej Waksmundzki, „Orbital”, (1999) nr 3, s. 191-194.

${ }^{21}$ A. Waksmundzki, R. Schreiter, Bibliografia prac autorów polskich z zakresu chromatografii i elektroforezy za lata 1947-1964, Warszawa 1970; Bibliografia prac autorów polskich z zakresu chromatografii za lata 1965-1971, Warszawa, 1975; Bibliografia prac autorów polskich z zakresu chromatografii za lata za lata 1972-1977, Warszawa 1982.

${ }^{22}$ J. Różyło, R. Schreiter, Bibliografia prac autorów polskich z zakresu chromatografii za lata 1978-1982, Lublin 1989.

${ }^{23}$ Trzydziestolecie pracy naukowej Tadeusza Margula, „Euhemer”, (1985) nr 2, s. 161-167 także bibliografia prac.

${ }^{24} \mathrm{~T}$. Margul, Międzynarodowa bibliografia religioznawstwa porównawczego w układzie działowym, Kraków 1984. Rec.: S. Korczak-Michalewski, „Nowe Książki”, (1987) nr 2, s. 130.

${ }^{25}$ L. Zdybel, Bibliografia filozofii polskiej (1918-1939), „Zeszyty Naukowe Wyższej Szkoły Inżynierskiej w Radomiu. Ekonomika. Prewencje. Ubezpieczenia”, 16 (1987) s. 47-120.

${ }^{26}$ Informacje pochodzą od autorów artykułu.

${ }^{27}$ H. Zins, Warsztat bibliograficzny historyka brytyjskiego, „Annales UMCS Sect. F”, 12 (1958) s. 183-202. 
zasadnicze znaczenie dla badacza zajmującego się historią Wielkiej Brytanii i dziejami powszechnymi. Ze względu na to, że większość omawianych bibliografii była trudno dostępna w Polsce i mało znana, przegląd taki był niezwykle przydatny i pożyteczny.

Ważnym osiągnięciem bibliograficznym pracowników KUL była bibliografia kartografii kościelnej w Polsce za lata $1851-1968^{28}$, przygotowana przez Jerzego Flagę, Ludomira Bieńkowskiego i Zygmunta Sułowskiego, pracowników Instytut Geografii Historycznej Kościoła w Polsce. Praca ukazała się w Leiden w 1971 r. pod patronatem Międzynarodowej Komisji Historii Porównawczej Kościołów (Commisoon Internationale d'Historie Eccclesiastigue Comparee). Na podkreślenie zasługuje fakt, iż było to pierwsze wyczerpujące zestawienie map dotyczących zjawisk religijnych w historiografii polskiej.

W 1981 r. ukazała się Bibliografia katolickich czasopism religijnych w Polsce 1918-194429, przygotowana pod redakcją ks. Zygmunta Zielińskiego, historyka Kościoła katolickiego. Praca dostarcza obfitego materiału do dziejów funkcjonowania Kościoła katolickiego w Polsce międzywojennej.

Pracownia Bibliograficzno-Edytorska Komisji Badań nad Literaturą Katolicką KUL ogłosiła w latach 1972-1982 zestawienia bibliografii Religia a literatura, adresowane do historyków literatury ${ }^{30}$. Obejmowały one lata 1966-1976. Autorami bibliografii byli pracownicy naukowi z Zakładu Badań nad Literaturą Religijną m.in. M. Jasińska-Wojtkowska, Maria Józefacka, Maria Kunowska-Porębna, Stefan Sawicki. To ambitne przedsięwzięcie spotkało się z dużym zainteresowaniem i przychylnym przyjęciem. Było pierwszym opracowaniem dokumentującym piśmiennictwo z zakresu relacji religia a literatura. Ważnym dorobkiem bibliograficznym Zakładu były bibliografie specjalistyczne podejmowane z własnej inicjatywy przez jego pracowników ${ }^{31}$. Na przypomnienie zasługuje Bibliografia

${ }^{28}$ L. Bieńkowski, J. Flaga, Z. Sułowski, Cartographie historique de la Pologne. Bibliographie des cartes concernant les rapports religieux dans les annes 1851-1968. - Bibliographie de cartographie ecclesiastique, Leiden 1971. Rec.: R. Nir, „Kwartalnik Historyczny”, 81 (1974) nr 1, s. 220-224; H. Hinkel, „Zeitschrift für Ostforschung”, 23 (1974) H. 2, s. 320-321.

${ }^{29}$ Bibliografia katolickich czasopism religijnych w Polsce 1918-1944, oprac. i red. Z. Zieliński, Lublin 1981. Rec.: A. Garlicka, „Kwartalnik Historii Prasy Polskiej”, 22 (1983) z. 2, s. 99-101.

${ }^{30}$ Religia a literatura. Bibliografia. Prace polskie 1966-1969, oprac. M. Błońska, M. Józefacka, M. Kunowska-Porębna, Lublin 1972; za lata 1970-1971, oprac. M. Błońska, J. Gotfryd, S. Kruk, M. Kunowska-Porębna, Lublin 1980; za rok 1975, red. M. Jasińska-Wojtkowska, S. Sawicki, Lublin 1982; za rok 1976, red. M. Jasińska-Wojtkowska, S. Sawicki, Lublin 1982. Rec.: 1966-1969: M. Drzewiecki, „Bibliotekarz”, (1973) nr 9, s. 282-284; Z. Irzyk, „Życie i Myśl”, (1973) nr 6, s. 141 142; A. Markowski, „Tygodnik Powszechny”, (1973) nr 15, s. 6; T. Tyszkiewicz, „Pamiętnik Literacki”, 64 (1973) z. 3, s. 341-343; W. Wilk, ,,Ruch Biblijny i Liturgiczny”, (1973) nr 4, s. 239-240.

${ }^{31}$ M. Jasińska-Wojtkowska, S. Sawicki, Przeglad polskich prac teoretyczno-literackich z zakresu genologii (1944-1957), „Zagadnienia Rodzajów Literackich”, 1 (1958) z. 1, s. 131-162; M. Błońska, M. Kunowska-Porębna, S. Sawicki, ,,Verbum” (1934-1939). Pismo i środowisko, t. 1-2, Lublin 1976; M. Kunowska -Porębna, , Kultura” (Poznań) 1936-1939. Bibliografia zawartości. Kartoteka. Biblioteka KUL. 
teorii literatury po 1945 r. przygotowana przez M. Jasińską-Wojtkowską. Niestety, dzieło to liczące ponad 4.200 pozycji, nie ukazało się drukiem ${ }^{32}$.

$\mathrm{Na}$ uwagę zasługuje również działalność bibliograficzna Leokadii Małunowicz, którą podjęła dopiero w okresie lubelskim. Z Katolickim Uniwersytetem Lubelskim związała się w 1950 r., po zwolnieniu z powodów politycznych z Uniwersytetu im. Mikołaja Kopernika w Toruniu. Oprócz zapoczątkowania bibliografii z zakresu katolickiej literatury religijnej w Polsce ${ }^{33}$, przygotowała Wstep do filologii klasycznej wraz z metodologia pracy umystowej $i$ naukowej (Lublin 1960), zawierający zasób podstawowych wiadomości z różnych dziedzin kultury antycznej, w tym zestawienie najważniejszych informacji bibliograficznych. Praca do dzisiaj cieszy się wielkim powodzeniem w dydaktyce uniwersyteckiej i nie tylko.

Lubelskie środowisko naukowe wiele uwagi poświęciło również regionalnym bibliografiom, które warunkują należyty rozwój badaniom regionalnym. O ile w pierwszym dziesięcioleciu powojennym wyniki pracy na polu bibliografii regionalnej były stosunkowo nikłe, o tyle w drugim dziesięcioleciu po 1956 r. zarysował się duży postęp na tym odcinku. Lubelska bibliografistyka regionalna cieszyła się szczególnym zainteresowaniem pracowników UMCS, zwłaszcza środowiska humanistycznego.

Szczególnie dużą kreatywność bibliograficzną wykazywał Jan Gurba, adiunkt w Katedrze Archeologii Polskiej i Powszechnej (1961), następnie kierownik (1974) Zakładu Archeologii Polskiej w Instytucie Historii w tymże uniwersytecie. Do zajmowania się bibliografią namówił go, prawdopodobnie, jego mistrz - Stefan Nosek, twórca lubelskiego ośrodka archeologicznego, który szacunek i poważanie dla twórczości bibliograficznej wyniósł z okresu pracy nad Bibliografia polska 1901-1925 przygotowywanej w okresie międzywojennym pod kierunkiem Jana Muszkowskiego, wybitnego bibliologa i bibliografa ${ }^{34}$. Już pod koniec lat 50. XX w. ujawnił J. Gurba zamiłowanie i zdolności do badań bibliograficznych, modnych wtedy bibliografii osobowych. W okresie pracy na uniwersytecie opracował zestawienia bibliograficzne z zakresu archeologii Lubelszczyzny ${ }^{35}$. Z czasem do prac bibliograficznych J. Gurba włączył swoich studentów m.in. Barbarę Bargiel, która już jako pracownik Katedry, a następnie Instytutu Archeologii z powodzeniem kontynuowała i rozwijała działalność bibliograficzną, ogłaszając zestawienia dotyczące pradziejów Lubelszczyzny ${ }^{36}$.

32 J. Czachowska, R. Loth, Przewodnik polonisty. Bibliografie, biblioteki, muzea literackie, Wrocław 1989, s. 148.

${ }^{33}$ L. Małunowicz, Wskazówki bibliograficzne z dziedziny katolickiej literatury religijnej w Polsce, ,Znak”, 10 (1958) nr 2-4, nr 6, nr 11-12; 11 (1959), nr 4.

${ }^{34}$ B. Kurek, Jan Muszkowski kontynuatorem prac Karola Estreichera, czyli historia pewnej bibliografii, w: Jan Muszkowski -ludzie, epoka, książki. Tradycje i kontynuacje, red. G. Czapnik, Z. Gruszka, J. Ladorucki. Łódź 2014, s. 127.

35 J. Gurba, 25 lat badań archeologicznych na Lubelszczyźnie w Polsce Ludowej, „Studia i Materiały Lubelskie", 5 (1971) s. 7-25.

${ }^{36}$ Pradzieje Lubelszczyzny w prasie lubelskiej. Bibliografia za lata 1960-1974, oprac. B. Bargieł [i in.], Lublin 1974. Rec. L. Gajewski, „Kwartalnik Historii Kultury Materialnej”, 24 (1975) 
Lubelskie jako jedno z nielicznych regionów Polski, obok Śląska i Pomorza, doczekało się bieżącej bibliografii historycznej. Inicjatywa w tym względzie wyszła z oddziału lubelskiego PTH. Za prezesury H. Zinsa w 1968 r. na łamach „Rocznika Lubelskiego” organu lubelskiego oddziału PTH, podjęto systematyczne ogłaszanie materiałów bibliograficznych do historii Lubelskiego ${ }^{37}$. Zestawienia te miały ułatwić przygotowanie kontynuacji retrospektywnej bibliografii historycznej A. Wojtkowskiego. Opracowanie zestawień bibliograficznych powierzono historykom młodego pokolenia UMCS (m.in. Annie Sochackiej, Ryszardowi Szczygłowi, Bożenie Nowak).

Ważny wkład $\mathrm{w}$ dokumentację piśmiennictwa regionalnego mieli również pracownicy Instytutu Filologii Polskiej. Na uwagę zasługuje bibliografia dialektologii Lubelszczyzny ${ }^{38}$ Józefa Kani oraz opisy prac językoznawczych opublikowanych m.in. w Lublinie i województwie lubelskim i rzeszowskim za lata 1964-1979, które dostarczał J. Bartmiński do bieżącego Przeglądu bibliograficznego ogłaszanego na łamach „Rocznika Slawistycznego"39. Teatr lubelski stał się silnym - a zarazem trwałym - przedmiotem zainteresowań badawczych Stefana Kruka. Jemu to poświęcił obszerne opracowanie bibliograficzne na temat repertuaru teatralnego w latach 1864-1890 (1979 ${ }^{40}$. Na podkreślenie zasługuje fakt, że praca ukazała się pod patronatem Instytutu Sztuki Polskiej Akademii Nauk w ramach serii Repertuary Teatrów w Polsce. Interesująca systematyzacja materiału (układ chronologiczny według sezonów), opis premier z obsadami oraz zamieszczanie recenzji teatralnych, wszystko to sprawia, że praca stanowi znakomite źródło do dziejów teatru w Lublinie.

Swój udział w ,zagospodarowaniu bibliograficznym” regionu lubelskiego mieli także pracownicy innych instytutów UMCS.

Niewątpliwie ważnym osiągnięciem było przygotowanie bibliografii Lubelskiego Zagłębia Węglowego (LZW) przez Jana Morawskiego i Jerzego Nowaka z Instytutu Nauk o Ziemi, Zakładu Geologii UMCS ${ }^{41}$. Publikacja stanowiła szczególnie wartościową i aktualną pozycję ze względu na ogólne zainteresowanie powstającym, drugim co do wielkości i zasobów, zagłębiem węglowym w Polsce. Była ona klasycznym przykładem bibliografii wyrosłej z bieżących potrzeb gospodarczych regionu, stanowiącym świadectwo związku nauki z regionem. Za-

s. 499-500; B. Bargieł, Popularyzacja archeologii lubelskiej w prasie lokalnej. Bibliografia za lata 1975-1980, Lublin 1981.

${ }^{37}$ Materiaty do bibliografii historii Lubelszczyzny za rok 1967, oprac. A. Wielgosz, „Rocznik Lubelski”, 11 (1968); toż za rok 1968, oprac. A. K. Gromek, Tamże, 12 (1969); toż za rok 1969, oprac. R. Szczygieł, tamże, 13 (1970); toż za rok 1970, oprac. B. Dobrzański, R. Szczygieł, tamże, 14 (1971); toż za lata 1971-1974, oprac. A. Sochacka, Tamże, 15-18 (1972-1975); toż za lata 19751992, oprac. B. Nowak, Tamże, 19-31 (1976-1991/ 1992).

${ }^{38}$ J. Kania, Bibliografia dialektologii Lubelszczyzny, „Językoznawstwo”, (1958) nr 1, s. 7-9.

${ }^{39}$ Przeglad bibliograficzny za lata 1964-1967, „Rocznik Slawistyczny”, 29 (1969) cz. 2-32 (1971) cz. 2.

${ }^{40}$ S. Kruk, Repertuar teatru lubelskiego 1864-1890, Warszawa 1979.

${ }^{41}$ J. Morawski, J. Nowak, Bibliografia Lubelskiego Zagłębia Węglowego, Lublin 1977. Rec.: Z. Gardziel, „Przegląd Geologiczny”, (1978) nr 9, s. 564. 
wierała cenne wiadomości o LZW nie tylko dla pracowników służby geologicznej, lecz także dla wszystkich zainteresowanych postępami badań dotyczących zagłębia lubelskiego.

Do bibliografii o trwałym znaczeniu dokumentacyjnym należy również spis prasy harcerskiej na Lubelszczyźnie w okresie międzywojennym, autorstwa Adama Winiarza, pracownika Instytutu Pedagogiki $\mathrm{UMCS}^{42}$. Zestawienie to było bardzo istotne, ponieważ dotykało zagadnienia mało znanego i dotąd nie podejmowanego.

Od końca lat 50. XX w. lubelskie środowisko naukowe żyło w stanie ustawicznego ,pogotowia bibliograficznego", podejmując coraz to nowe inicjatywy w zakresie bibliografii osobowych naukowców. Występowały one już wcześniej, ale sporadycznie. Bibliografie osobowe na nowo odżyły po restrykcjach okresu stalinowskiego. Cechowała je duża rozpiętość: od bibliografii naukowców (dawniejszych i współczesnych), poprzez bibliografie wydziałów i instytutów, kończąc na zestawieniach katedr, zakładów oraz sekcji. Dyktowały je najczęściej okoliczności rocznicowe i jubileuszowe.

Bibliografie osobowe powstawały zwykle w gronie uczniów, współpracowników, kolegów i przyjaciół uczonych. Dominowało na tym polu niewątpliwie środowisko humanistyczne, szczególnie historyczne. Przeważnie tego rodzaju bibliografie ukazywały się $\mathrm{w}$ księgach pamiątkowych ${ }^{43}$ lub czasopismach ${ }^{44}$, a samoistne zdarzały się najczęściej jako odbitki. Nie znaczy to, że brak było w ogóle bibliografii naukowców wydanych osobno. W omawianym okresie opublikowano szereg bibliografii na łamach czasopism „Annales UMCS”45 i „Archiwa, Biblioteki i Muzea Kościelne"46.

${ }^{42}$ A. Winiarz, Bibliografia prasy harcerskiej na Lubelszczyźnie w latach 1918-1939, „Harcerstwo" (1987) nr 11-12, s. 37-41.

${ }^{43}$ Zob. np. H. Gmiterek, Bibliografia publikacji Stanisława Tworka (1958-1979), w: 500-lecie Grzegorza z Sanoka, [red. A. Krawczyk, A. Nowicki], Lublin 1979, s. 12-21; H.I. Szumił, Bibliografia podmiotowa i przedmiotowa ks. prof. dra Wincentego Granata, w: Tajemnica czlowieka. Wokót osoby i myśli ks. prof. dra Wincentego Granata, red. Cz. Bartnik [i in.], Lublin 1985, s. 61-100;

${ }^{44}$ Zob. np. J. Kłoczowski, W. Nowodworski, Bibliografia prac prof. Leona Białkowskiego, „Roczniki Humanistyczne”, 4 (1953) z. 4, s. 300-309; E. Wiśniowski, Prof. dr hab. Ryszard Bender, „Chrześcijanin w Świecie”, 12 (1980) nr 9, s. 53-60; J. Gurba, Bibliografia prac drukowanych prof. dr. Aleksandra Gardawskiego (1946-1973), „Rocznik Lubelski”, 17 (1974) s. 326-330.

${ }^{45} \mathrm{~Np}$. Jan Blaton (wspomnienie pośmiertne) $i$ spis prac, oprac. S. Jedynak, „Annales UMCS. Sect. AA”, 2 (1948), s. VII-IX; Bibliografia prac Juliusza Willaume'a, oprac. R. Orłowski, „Annales UMCS. Sect. F”, 11 (1956), s. 171-178; Bibliografia prac prof. dr. Tadeusza Mencla, zest. S. Wiśniewski, „Annales UMCS. Sect. F.”, 37 (1982), s. VIII-XX.

${ }^{46}$ Zob. np. M. Jędrzejczak, Bibliografia prac drukowanych ks. Pawła Antoniego Czapiewskiego, „Archiwa, Biblioteki i Muzea Kościelne” (dalej: ABMK), 9 (1964) s. 84-92; Bibliografia opublikowanych prac ks. prof. dra Teofila Dlugosza za lata 1916-1971, zest. M. Leszczyński, ABMK, 43 (1981), s. 247-259; T. Madała, Bibliografia prac Witolda Nowodworskiego, syna (1907-1978), ABMK, 40 (1980) s. 170-177; W. Nowodworski, Bibliografia prac prof. Leona Biatkowskiego, ABMK, 15 (1967) s. 271-282; H.I. Szumił, Bibliografia podmiotowa i przedmiotowa biskupa profesora Walentego Wójcika, ABMK, 64 (1995) s. 601-629. 
Znawcą problematyki bibliografii osobowej naukowców był niewątpliwie ks. Stanisław Librowski, historyk i archiwista, pracownik KUL. Można przypuszczać, że wzrost zainteresowania bibliografiami tego rodzaju w środowisku uniwersyteckim oraz praca własna nad nimi ${ }^{47}$ były inspiracją do głębszego zainteresowania się ks. S. Librowskiego problemami metodycznymi bibliografii osobowej pracowników nauki, zwłaszcza humanistów. Spod jego pióra wyszedł poradnik metodyki bibliografii osobowej pracowników nauki zawierający zalecenia praktyczne dotyczące opracowania spisów tego rodzaju ${ }^{48}$. Praca ta z pewnością odegrała ważną rolę $\mathrm{w}$ upowszechnianiu prawidłowych zasad sporządzania bibliografii osobowych, szczególnie wśród pracowników KUL. Mało znanym faktem jest, że ks. S. Librowski pozostawił w maszynopisie Bibliografie pracowników Instytutu Kościoła KUL ${ }^{49}$.

Zwyczaj bibliograficznego utrwalania dorobku naukowego rozciągnął się również na dzieje instytucji naukowych. O powstaniu bibliografii zespołów osobowych decydowały w głównej mierze względy okolicznościowe. Bodźcem do podjęcia wielu prac były jubileusze związane z rocznicami utworzenia uczelni, wydziałów, zakładów i sekcji. Oto niektóre przykłady. I tak jubileusz 50 i 60 -lecia istnienia Katolickiego Uniwersytetu Lubelskiego, uczczono licznymi zestawieniami bibliograficznymi zespołów osobowych ${ }^{50}$. Gdy Wydział Ekonomiczny UMCS święcił swoje 6-lecie funkcjonowania ogłoszono bibliografię prac naukowych jego pracowników, przygotowaną zapewne z inicjatywy Ryszarda Orłowskiego, znanego z zainteresowań bibliograficznych, której opracowanie powierzono bibliotekarzom Biblioteki UMCS ${ }^{51}$. Z okazji 20-lecia Zakładu Kartografii UMCS ogłoszono wykaz publikacji pracowników oraz spis prac magisterskich wykonanych w Zakładzie w latach 1964-1984². Jan Ziółek opracował biblio-

${ }^{47}$ Do jego prac należą m.in. Bibliografia prac opublikowanych ks. prof. dra Mariana Rechowicza, zest. S. Librowski przy udziale W. Nowodworskiego, ABMK, 21 (1970) s. 9-20; Bibliografia prac opublikowanych prof. dra Mariana Rechowicza, „Roczniki Teologiczno-Kanoniczne”, 24 (1977) z. 4, s. 11-24 oraz mniejsze zestawienia bibliograficzne (bp. Michała Kozala, bp. Hieronima Rozrażewskiego), a także autobibliografia, ogłoszona anonimowo, Bibliografia adnotowana ks. prof. dra hab. Stanisława Librowskiego (w 60-lecie urodzin i 35 lecie pracy naukowej), ABMK, 30 (1975) s. 321-347.

${ }^{48}$ S. Librowski, Bibliografie osobowe pracowników nauki oraz ich przygotowanie, ABMK, 36 (1978) s. 6-16.

${ }^{49}$ W. Kujawski, Ks. Stanisław Librowski włocławski historyk i archiwista, „Studia Włocławskie", 10 (2007) s. 77.

${ }^{50}$ Zob. Bibliografia Lubelszczyzny 1965-1970, Lublin 1982; Bibliografia Lubelszczyzny 19761980. Lublin 2004.

${ }^{51}$ T. Gaworczyk, J. Olczak, Bibliografia publikacji naukowych pracowników Wydziału Ekonomicznego Uniwersytetu im. Marii Curie-Skłodowskiej w Lublinie za lata 1965-1971, w: Problemy rozwoju Wydziatu Ekonomicznego, red. W. Holtzman, R. Orłowski, Lublin 1974, s. 1-81.

5220 [Dwadzieścia] lat Zakładu Kartografii Uniwersytetu Marii Curie-Skłodowskiej w Lublinie, Lublin 1984, s. 31-49; W. Czechowska, J. Mościbroda, Wykaz publikacji pracowników Zaktadu Kartografii Instytutu Nauk o Ziemi UMCS w Lublinie za lata 1964-1984, s. 50-60; L. Grzechnik, Z. Kalisz, Wykaz prac magisterskich wykonanych $w$ Zaktadzie Kartografii UMCS $w$ Lublinie w latach 1964-1984. 
grafię dorobku pracowników zatrudnionych w Sekcji Historii na Wydziale Nauk Humanistycznych i Instytucie Geografii Historycznej Kościoła w Polsce KUL $\mathrm{z}$ lat $1918-1971^{53}$. Bywały też zestawienia prac pracowników z zakresu danego zagadnienia $^{54}$.

Dokonania naukowe młodych pracowników Zakładu Matematyki Stosowanej Politechniki Lubelskiej udokumentowano odpowiednim spisem zamieszczonym w pracy na temat ich działalności i dorobku na niwie naukowej ${ }^{55}$. Z kolei z inicjatywy J. Gurby sporządzono wykaz prac członków Koła Naukowego Archeologów za lata $1965-1983^{56}$. Natomiast za sprawą pracowników naukowych i przy współudziale studentów Instytutu Nauk o Ziemi, ukazała się Bibliografia Bieszczadzkiej Stacji Naukowej UMCS za lata 1961-198357.

Oprócz dominujących zestawień retrospektywnych pojawiły się również bieżące bibliografie zespołów osobowych. Jedną z pierwszych inicjatyw w tym względzie podjęli pracownicy Wydziału Weterynarii Akademii Rolniczej w Lublinie. W 1962 r. zaczęli oni wydawać czasopismo „Excerpta Veterinaria”, dokumentujące ich dorobek badawczy.

Początkowo wykazy prac dyplomowych (habilitacyjnych, doktorskich, magisterskich) umieszczano obok spisu prac pracowników instytutu czy zakładu. Pierwszym wydawnictwem samoistnym ciągłym, rejestrującym prace dyplomowe, była Bibliografia prac habilitacyjnych, doktorskich i magisterskich wykonanych w Akademii Rolniczej w Lublinie. Ukazywała się ona pod redakcją Edmunda Prosta, kierownika Katedry Higieny Żywności, a także rektora AR w latach 19811987. Opracowaniem bibliografii zajęła się Biblioteka Główna AR pod kierunkiem Edwarda Maruszaka.

W sferze zainteresowań lubelskich uczonych były również bibliografie określonej formy wydawniczej. Reprezentowane są one przez bibliografie zawartości czasopism. Jako przykład można podać bibliografię zawartości półrocznika „Archiwa, Biblioteki i Muzea Kościelne”, której zestawienie przygotował założyciel i redaktor naczelny czasopisma ks. S. Librowski ${ }^{58}$.

Po 1989 r. głębokie zmiany polityczno-społeczne, decentralizacja nauki polskiej oraz oddzielenie jej od wpływów politycznych i ideologicznych, otworzyły

${ }^{53}$ J. Ziółek, Bibliografia publikacji pracowników Sekcji Historii na Wydziale Nauk Humanistycznych i Instytutu Geografii Historycznej Kościoła w Polsce Katolickiego Uniwersytetu Lubelskiego z lat 1918-1971, ABMK, 27 (1973) s. 261-324.

${ }^{54}$ Zob. np. B. Adamczyk, Spektometria mas i elektromagnetyczna separacja izotopów w lubelskim ośrodku fizyk, s. 7-11: Wykaz najważniejszych publikacji z zakresu spektrometrii mas pracowników lubelskiego ośrodka fizyki [Instytutu Fizyki Uniwersytetu Marii Curie-Skłodowskiej w Lublinie], „Annales. UMCS Sect. AAA”, 36/37 (1981/1982).

${ }^{55}$ Wykaz publikacji, w: Dorobek młodych pracowników Zakładu Matematyki Stosowanej Politechniki Lubelskiej, red. J. Burdzy [i in.], Lublin 1979, s. 49-88.

${ }^{56}$ B. Rutkowska, Bibliografia prac członków Koła Naukowego Archeologów za lata 1965-1983, Lublin 1985.

${ }^{57}$ Bibliografia Bieszczadzkiej Stacji Naukowej UMCS za lata 1961-1983, „Prace. Studenckiego Koła Naukowego Geografów UMCS” (1982), s. 9-16.

${ }^{58}$ S. Librowski, Bibliografia zawartości czasopisma Archiwa, Biblioteki i Muzea Kościelne. Tomy 1-50, ABMK, 52 (1986) s. 5-56. 
drzwi pracownikom nauki do nieskrępowanego podejmowania różnych inicjatyw i prac bibliograficznych. Widać to także na przykładzie lubelskiego środowiska naukowego, którego aktywność, kreatywność i dynamizm działania znacząco wzrosły na polu bibliograficznym w stosunku do wcześniejszego okresu. Znalazło to odbicie nie tylko w ilości opublikowanych opracowań bibliograficznych, ale także $\mathrm{w}$ ich różnorodnej tematyce i uprawianych typach bibliografii.

Niesłabnącym zainteresowaniem nadal cieszyły się bibliografie osobowe. Szczególnie dużo uwagi poświęcili im uczeni związani z Uniwersytetem Marii Curie-Skłodowskiej i Katolickim Uniwersytetem Lubelskim. Znacznie rzadziej były one tworzone w środowisku Akademii Medycznej, Akademii Rolniczej i Politechniki Lubelskiej.

Najczęstszym powodem ich powstawania, podobnie jak w okresie wcześniejszym, były rozmaite rocznice związane z życiem uczonych, takie jak: jubileusz pracy naukowej, rocznica urodzin, a czasem również połączone obydwa te wydarzenia. Ponadto przygotowywano je w celu podkreślenia zasług i uczenia pamięci zmarłych przedstawicieli świata naukowego.

W gronie twórców omawianych bibliografii znajdują się nie tylko uczniowie, współpracownicy, koledzy oraz przyjaciele uczonych, ale też spotyka się członków ich rodzin. I tak na przykład bibliografię osobową, badacza dziejów powszechnych i historii Polski XIX w., J. Ziółka, opracowała jego córka, Ewa Małgorzata Ziółek ${ }^{59}$, która podobnie jak jej ojciec, jest historykiem specjalizującym się w dziejach Polski XIX w. Z kolei w przygotowaniu dwóch zestawień publikacji historyka Kościoła i zarazem znawcy dziejów szkolnictwa i wychowania, Stanisława Litaka, miała udział jego żona Teresa ${ }^{60}$. Niekiedy również sami zainteresowani przygotowywali zestawienia swojej twórczości. Autobibliografie stworzyli Henryk Piersa ${ }^{61}$ i Urszula Wich ${ }^{62}$.

Autorzy większości spisów, mimo iż są z reguły bibliografami-amatorami, cechują się rozwiniętą świadomością bibliograficzną. Doceniając rolę i znaczenie bibliografii jako ważnego źródła informacji pośredniej, tworzyli przede wszystkim bibliografie osobowe podmiotowe. Dbali w nich o jak najpełniejsze ukaza-

${ }^{59}$ Bibliografia prac prof. dra hab. Jana Ziótka za lata 1969-2000, zest. E. M. Ziółek, w: Ojczyzna i wolność. Prace ofiarowane Profesorowi Janowi Ziótkowi w siedemdziesiata rocznice urodzin, red. A. Barańska, W. Matwiejczyk, E.M. Ziółek, Lublin 2000, s. 27-40. Zestawiła ona także Wykaz rozpraw magisterskich i doktorskich wykonanych pod kierunkiem prof. dra hab. Jana Ziótka, w: tamże, s. 41-47.

${ }^{60}$ Por. Bibliografia prac Stanisława Litaka za lata 1958-2001, oprac. T. Litak, w: Religie, edukacja, kultura. Ksiega pamiątkowa dedykowana profesorowi Stanisławowi Litakowi, red. M. Surdacki, Lublin 2002, s. 743-766 oraz Bibliografia prac Stanisława Litaka za lata 1958-2010, oprac. T. Litak, J. Szady, w: Vir honestus ac bonus Stanistaw Litak 1932-2010, red. P.P. Gach, M. Surdacki, Lublin 2011, s. 227-251.

${ }^{61}$ Publikacje prof. dra hab. Henryka Piersy, „Roczniki Filozoficzne”, 52 (2004) z. 1, s. 9-16. $\mathrm{Na}$ temat autorstwa zob. Bibliografia Lubelszczyzny 2000-2004, http://www.hieronim.wbp.lublin. pl/ (dostęp: 8.06.2017).

${ }^{62}$ Wykaz publikacji naukowych prof. dr hab. Urszuli Wich, „Annales UMCS. Sect. H”, 47 (2013) z. 1, s. 11-28. O autorstwie informuje Bibliografia Lubelszczyzny 2005-2017, http://www. hieronim.wbp.lublin.pl/(dostęp: 8.06.2017). 
nie wizerunku twórczego ludzi nauki. Aby to osiągnąć dążyli do kompletności $\mathrm{w}$ doborze materiału, co jest zgodne z wytycznymi metodyki bibliograficznej. Prezentowali przeważnie całokształt twórczości poszczególnych uczonych, poczynając od daty ich debiutu, aż po rok zamknięcia prac nad danym spisem. Rejestrowali rozmaite formy wydawnicze i piśmiennicze. Uwzględniali prace naukowe, popularnonaukowe i popularyzatorskie. Do zestawu publikacji dołączali niejednokrotnie spis dzieł oddanych do druku. Często zamieszczali też wykazy prac doktorskich i magisterskich powstałych pod kierunkiem uczonych. Niekiedy informowali o ich udziale w przewodach doktorskich, postępowaniach habilitacyjnych i o opiniach przy nominacjach profesorskich ${ }^{63}$. Poprzez tego typu dodatki podkreślano wkład starszego pokolenia uczonych w kształcenie i rozwój młodej kadry naukowej.

Troszcząc się o kompletność, twórcy bibliografii ogłaszali kontynuacje wcześniejszych zestawień, dodając do nich nieraz uzupełnienia ${ }^{64}$.

Bardzo dużą aktywność w tworzeniu podmiotowych bibliografii osobowych wykazują pracownicy Ośrodka Badań nad Myślą Jana Pawła II - Instytutu Jana Pawła II KUL. Ogłaszają oni systematycznie na łamach „Ethosu”, poczynając od pierwszego rocznika tego periodyku (1988) po chwilę obecną, retrospektywną bibliografię wypowiedzi Jana Pawła II, a ostatnio także Benedykta XVI i papieża Franciszka na rozmaite ważkie i zarazem aktualne tematy dotyczące m.in. ekonomii, etyki, filozofii, politologii, socjologii i teologii ${ }^{65}$. Ponadto w środowisku KUL zainicjowano w 2004 r. bieżącą Bibliografię podmiotowa polskich historyków Kościoła, która wychodzi cyklicznie do chwili obecnej ${ }^{66}$.

W lubelskim środowisku naukowym powstawały także bibliografie osobowe o charakterze mieszanym podmiotowo-przedmiotowym. Są one najpełniejszą i najbardziej przydaną z punktu widzenia odbiorcy formą bibliografii osobowej. Pozwalają bowiem na wielopłaszczyznowe badania w zakresie wielu dyscyplin naukowych, służą pomocą naukoznawstwu i bibliometrii oraz są niezastąpionym

${ }^{63}$ Zob. np. F. Czyżewski, M. Sajewicz, Wykaz prac prof. dr. hab. Michała Łosiowa, w: 75-lecie urodzin profesora Michała Łosiowa. Dorobek naukowo-dydaktyczny i działalność społeczna, Lublin-Łuck 2003, s. 21-104 oraz W. Paruch, M. Wichmanowski, Działalność naukowa - bibliografia prac Profesora zw. dr. hab. Jana Jachymka i prac napisanych pod jego naukowym kierunkiem, „Annales UMCS. Sect. K”, 6 (1999) s. 9-25.

${ }^{64}$ Zob. np. A. Matczuk, Bibliografia prac profesora Józefa Szymańskiego za lata 1992-2000 z uzupetnieniami, w: Droga historii. Studia ofiarowane profesorowi Józefowi Szymańskiemu w siedemdziesiąta rocznice urodzin, red. P. Dymmel, K. Skupieński, B. Trelińska, Lublin 2001, s. 1722. Uzupełnienia dotyczą zestawienia: A. Matczuk, Bibliografia prac Józefa Szymańskiego [za lata 1958-1991], w: Discernare vera ac falsa. Prace ofiarowane Józefowi Szymańskiemu w sześćdziesiata rocznice urodzin, Lublin 1992, s. 9-34. Por. też Bibliografia prac doc. dr. Jana Gurby, oprac. T. Gaworczyk, Lublin 1988 oraz Bibliografia prac doc. dr. Jana Gurby za lata 1988-2003, oprac. U. Kurzątkowska, w: Przez pradzieje $i$ wczesne średniowiecze. Księga jubileuszowa na siedemdziesiate piąte urodziny docenta Jana Gurby, red. J. Libera, A. Zakościelna, Lublin 2004, s. 15-28.

${ }^{65}$ Zob. „Ethos”, 1(1988) - 29 (2016).

${ }^{66}$ Bibliografia podmiotowa polskich historyków Kościoła za lata 2000-2002, oprac. J. Walkusz [i in.], „Kościół w Polsce”, 3 (2004) s.229-350. Ostatnie zestawienie za rok 2015 z uzupełnieniami za lata 2000-2014 oprac. J. Walkusz, M. R.Górniak, „Kościół w Polsce”, 16 (2017) s. 263-314. 
źródłem informacji w biografistyce. Takie spisy przygotowano m.in. ks. Antoniemu Kościowi ${ }^{67}$ i Albinowi Koprukowniakowi ${ }^{68}$.

Bibliografie osobowe mają przeważnie układ chronologiczny, który pomaga zorientować się w dorobku i rozwoju zainteresowań twórczych poszczególnych osób oraz dostarcza informacji na temat znaczenia i popularności ich prac.

Większość lubelskich ośrodków naukowych dużym zainteresowaniem otacza $\mathrm{w}$ dalszym ciągu bibliografie zespołów osobowych. O ich tworzeniu, podobnie jak w przypadku bibliografii osobowych, decyduja przede wszystkim względy okolicznościowe. Bezpośrednim impulsem do podjęcia wielu inicjatyw bibliograficznych były jubileusze związane z rocznicami powstania uczelni wyższych oraz funkcjonujących w ich obrębie jednostek - wydziałów, instytutów, katedr, zakładów, a nawet sekcji i zespołów badawczych. Można sądzić, że do intensywnego ich rozwoju przyczyniła się decentralizacja nauki przeprowadzona $\mathrm{w}$ latach 90. XX w. W obecnych warunkach, o swój wizerunek muszą troszczyć się nie tylko poszczególne uczelnie, ale także funkcjonujące $w$ ich obrębie jednostki podrzędne. Jedną z najlepszych form promocji jest pokazanie swoich osiągnięć badawczych i potencjału naukowego. Dobrym narzędziem do realizacji tego typu zadań są właśnie bibliografie zespołów osobowych. Stąd tak duże nimi zainteresowanie w ostatnim okresie.

Podobnie jak w latach wcześniejszych tworzone były różne rodzaje i formy bibliografii zespołów osobowych. Preferowano retrospektywne zestawienia podmiotowe pokazujące dorobek naukowy poszczególnych instytucji za zamknięte, niejednokrotnie długie przedziały czasu.

Warto w tym miejscu przytoczyć kilka przykładów. Jubileusz 50. lecia działalności Wydziału Prawa i Administracji UMCS, obchodzony w 1999 r., stał się okazją do przygotowania i wydania pokaźnej Bibliografii publikacji pracowników naukowych wydziatu (Lublin 1999), zrodzonej z inspiracji specjalisty w dziedzinie prawa karnego Tadeusza Bojarskiego, ówczesnego dziekana tego Wydziału. Rejestruje ona piśmiennictwo za lata 1949-1998. Dzieło to doczekało się kontynuacji w postaci kolejnego spisu, obejmującego materiał za pięciolecie 1999$2003^{69}$. Retrospektywnym zestawieniem jest również obszerna, licząca niemal 700 stronic, Bibliografia dorobku naukowego pracowników Instytutu Filologii Polskiej UMCS do roku 2013 (Lublin 2014), przygotowana pod redakcją bardzo aktywnych bibliograficznie pracowników Pracowni Archiwum Etnolingwistycznego, działającej w ramach Instytutu Filologii Polskiej UMCS - Beaty Maksymiuk-Pacek i Stanisławy Niebrzegowskiej-Bartmińskiej. Pokazuje ona zainte-

${ }^{67}$ J. Potrzeszcz, Bibliografia podmiotowa i przedmiotowa księdza profesora Antoniego Kościa SVD, w: Abiit, non obiit. Księga poświęcona pamięci księdza profesora Antoniego Kościa SVD, red. A. Dębiński [i in.], Lublin 2013, s. 27-38.

${ }^{68}$ Wykaz publikacji prof. dr. hab. Albina Koprukowniaka za lata 1955-2009, oprac. H. Bałabuch, A. Przegaliński, S. Wiśniewski, w: Bibliografia publikacji naukowych prof. dr. hab. Albina Koprukowniaka, Lublin 2009, s. 13-49 oraz Ważniejsze publikacje o działalności naukowej prof. dr. hab. Antoniego Koprukowniaka, zest. S. Wiśniewski, w: Bibliografia publikacji naukowych prof. dr. hab. Albina Koprukowniaka, s. 52-54.

${ }^{69}$ Bibliografia publikacji naukowych pracowników wydzialu w latach 1999-2003, Lublin 2005. 
resowania badawcze poszczególnych osób zatrudnionych w Instytucie za okres 60 lat istnienia polonistyki w UMCS. Wymienione autorki stworzyły również wartościową bibliografię publikacji lubelskiego zespołu etnolingwistycznego, wydaną w postaci dwóch odrębnych książek. Jej pełniejsza wersja dokumentuje piśmiennictwo lubelskich etnolingwistów za lata 1959-2009 ${ }^{70}$. Ważnym osiągnięciem lubelskiego środowiska naukowego jest także bibliografia pracowników Instytut Archeologii UMCS, zestawiona przez Urszulę Kurzątkowską ${ }^{71}$. Powstała ona z okazji 60 rocznicy utworzenia w UMCS Katedry Prehistorii, poprzedniczki obecnego Instytutu Archeologii. Jest to pierwsza w dziejach Instytutu kompletna bibliografia prac drukowanych, dokumentująca twórczość naukową, popularnonaukową i popularyzatorską archeologów związanych z UMCS za okres 60 lat $^{72}$. Pionierski charakter ma również Bibliografia publikacji pracowników Zakładu Nauk Pomocniczych Historii i Bibliotekoznawstwa UMCS oraz wykaz prac habilitacyjnych, doktorskich i magisterskich wykonanych w latach 1977-2003 (Lublin 2007), przygotowana przez historyka i teoretyka bibliografii i zarazem bibliografa-praktyka Alicję Matczuk. Autorka zaprezentowała w niej całościowy dorobek naukowy i dydaktyczny Zakładu za okres 26 lat jego istnienia. Bibliografia jest zarazem formą podsumowania osiągnięć badawczych Zakładu w związku z wydzieleniem z jego struktury w 2003 r. Instytutu Bibliotekoznawstwa i Informacji Naukowej.

Obok spisów retrospektywnych rozwijały się i nadal powstają bieżące bibliografie zespołów osobowych. Informują one w sposób ciągły o najnowszych publikacjach lubelskich uczonych. Są to zarówno kontynuacje wcześniejszych wykazów, jak też nowopowstałe zestawienia.

Swoją bieżącą bibliografię wydaje w dalszym ciągu Wydział Weterynarii Akademii Rolniczej, a od 2008 r. Uniwersytetu Przyrodniczego w Lublinie, w postaci regularnie ogłaszanego periodyku „Excerpta Veterinaria”, redagowanego obecnie przez Grażynę Ziółkowską.

W 1998 r. pojawiła się bieżąca Bibliografia prac pracowników Wydziału Politologii UMCS. Pierwszy spis, obejmujący materiał za lata 1994-1995, został opracowany przez Waldemara Parucha i Krystynę Trembicką ${ }^{73}$. Bibliografia była publikowana cyklicznie do 2006 roku, kiedy to ukazało się jej ostatnie zestawienie za rok $2004^{74}$.

70 Por. Bibliografia adnotowana lubelskiego zespotu etnolingwistycznego (do roku 2008), oprac. B. Maksymiuk-Pacek, S. Niebrzegowska-Bartmińska, Lublin 2008 oraz Bibliografia adnotowana lubelskiego zespotu etnolingwistycznego (do roku 2009), oprac. B. Maksymiuk-Pacek, S. Niebrzegowska-Bartmińska, Lublin 2009.

${ }^{71}$ U. Kurzątkowska, Materiaty do bibliografii pracowników Instytut Archeologii UMCS za lata 1945-2005, w: 60 lat archeologii w UMCS. Podsumowanie ostatniego dziesięciolecia, red. J. Gurba, J. Libera, Lublin 2007, s. 173-380.

72 Tamże, s. 173.

${ }^{73}$ Bibliografia prac pracowników Wydziału Politologii UMCS za lata 1994-1995, oprac. W. Paruch, K. Trembecka, „Annales UMCS. Sect. K”, (1998) s. 263-176.

${ }^{74}$ Bibliografia prac pracowników Wydziału Politologii UMCS za rok 2004, „Annales UMCS. Sect. K”, 13 (2006), s. 171-183; s. 185-192; s. 193-200. 
Od 2007 r. analogiczną bibliografią legitymuje się Wydział Prawa, Prawa Kanonicznego i Administracyjnego KUL. Bieżąca bibliografia dorobku pracowników Wydziału jest ogłaszana na łamach czasopisma „Studia Prawnicze KUL”. Rozpoczęło ją zestawienie za rok 2000, przygotowane przez Jadwigę Potrzeszcz ${ }^{75}$. Bibliografia jest wydawana po dzień dzisiejszy, a ostatnio opublikowany spis rejestruje publikacje za rok $2009^{76}$.

W doborze materiału autorzy bibliografii zespołów osobowych nie zawsze dążą do kompletności. Niektórzy ograniczają rejestrowane piśmiennictwo tylko do prac naukowych bądź do określonego typu dokumentu. Na przykład Robert Kozyrski, badacz dziejów Kościoła, w swojej Bibliografii map i planów opracowanych w Instytucie Geografii Historycznej Kościoła w Polsce KUL wydanych w latach 1956-2000 (Lublin 2001), uwzględnił wyłącznie dokumenty kartograficzne. Inni z kolei prezentują tylko wybrane formy piśmiennicze. Tworzą wykazy rozpraw habilitacyjnych, prac doktorskich, magisterskich, licencjackich i dyplomowych, niekiedy z zawężeniem do określonej tematyki.

Te ostatnie są wydawane zarówno jako integralna część bibliografii poszczególnych zespołów naukowych, czego egzemplifikacją jest wspomniana już $B i$ bliografia publikacji pracowników Zakładu Nauk Pomocniczych Historii i Bibliotekoznawstwa UMCS, jak też wychodzą jako odrębne, samodzielne publikacje. Niekiedy mają postać wręcz monumentalnych opracowań zwartych, jak np. $D y$ sertacje doktorskie i habilitacyjne wykonane na wydziałach lekarskim i farmaceutycznym UMCS i Akademii Medycznej w Lublinie (Lublin 2000), liczące bez mała 500 stronic, zredagowane przez Andrzeja Wróbla, historyka farmacji i badacza dziejów medycyny, pracownika Zakładu Historii Nauk Medycznych Akademii Medycznej w Lublinie, wydane z okazji jubileuszu 50-lecia lubelskiej uczelni medycznej.

Tego typu spisy odgrywają bardzo ważną rolę. Informują bowiem świat naukowy o podjętych tematach oraz umożliwiają wytyczenie nowych obszarów badawczych ${ }^{77}$.

Uczeni lubelscy wykazują aktywność nie tylko w tworzeniu bibliografii pracowników uczelni wyższych, ale też podejmują inicjatywy przygotowania bibliografii osobowych innych instytucji, działających także poza Lublinem. Trudu opracowania takich spisów podjęła się dwukrotnie A. Matczuk. Wspólnie z Tomaszem Kranzem przygotowała Bibliografie publikacji pracowników Państwowego Muzeum na Majdanku (Lublin 2004). Praca ta jest pierwszą pełną bibliografią podmiotową pracowników Muzeum, rejestrującą publikacje za lata 1947-2003. A. Matczuk opracowała również Bibliografie wydawnictw Towarzystwa Przy-

${ }^{75}$ Bibliografia pracowników naukowych Wydziatu Prawa, Prawa Kanonicznego i Administracji Katolickiego Uniwersytetu Lubelskiego Jana Pawła II za rok 2000, oprac. J. Potrzeszcz, „Studia Prawnicze KUL", (2007) nr 1, s. 233-268.

${ }^{76}$ Bibliografia pracowników naukowych Wydziału Prawa, Prawa Kanonicznego i Administracji Katolickiego Uniwersytetu Lubelskiego Jana Pawła II za rok 2009, oprac. W.Sz. Staszewski, M. Wójcik, „Studia Prawnicze KUL”, (2010) nr 3, s. 129-170.

${ }^{77}$ A. Znajomski, Bibliografie zespołów osobowych - instytucji. Stan i potrzeby, w: Bibliografia. Teoria, praktyka, dydaktyka, red. J. Woźniak-Kasperek, M. Ochmański, Warszawa 2009, s. 125. 
jaciót Janowca oraz zawartości „,Notatnika Janowieckiego” (Janowiec 2016), będącą efektem kooperacji autorki z Towarzystwem. Piotr Dymmel, znawca nauk pomocniczych historii, piastujący obecnie funkcję dyrektora Archiwum Państwowego w Lublinie, jest współtwórcą Bibliografii publikacji pracowników Archiwum Państwowego w Lublinie 1918-200878. Dokumentuje ona całościowy dorobek piśmienniczy pracowników Archiwum lubelskiego za okres 90 lat jego funkcjonowania.

Obok bibliografii podmiotowych przygotowuje się również spisy przedmiotowe, aczkolwiek jest to zjawisko marginalne. Takim spisem dysponuje Instytut Badań nad Polonią i Duszpasterstwem Polonijnym Katolickiego Uniwersytetu Lubelskiego ${ }^{79}$. Zestawiono w nim publikacje poświecone Instytutowi za cały okres jego działania, od momentu powstania w 1972 r. po rok 2002, kiedy to obchodzono 30-lecie funkcjonowania tej placówki badawczej.

Należy też wspomnieć, że nie wszystkie przedsięwzięcia w zakresie bibliografii zespołów osobowych zostały zrealizowane. Niepowodzeniem zakończyły się prace prowadzone przez pracowników Zakładu Nauk Pomocniczych Historii i Bibliotekoznawstwa UMCS nad retrospektywną bibliografią publikacji naukowych pracowników UMCS za lata 1944-1994 oraz nad bibliografią publikacji naukowych pracowników Wydziału Humanistycznego UMCS za lata 1952-2002. Obydwie bibliografie, zrodzone z inicjatywy J. Szymańskiego, miały uświetnić, odpowiednio: pierwsza jubileusz 50-lecia uczelni, przypadający w 1994 r., a druga 50-lecie istnienia Wydziału Humanistycznego UMCS, obchodzone w 2002 r. Pomimo dużego zaangażowania pracowników Zakładu, wypracowania koncepcji obydwu spisów, przygotowania oprogramowania komputerowego, zgromadzenia materiału i w znacznym stopniu jego opracowania, przeprowadzenia kwerend archiwalnych i bibliotecznych w celu stworzenia listy pracowników UMCS oraz prymarnej weryfikacji opisów, nie udało się ich wydać z powodu problemów finansowych.

Okres po 1989 r. przyniósł dalszy rozwój bibliografii dziedzinowych regionalnych. Niewątpliwie najważniejszym osiągnięciem tego czasu było sfinalizowanie w 2000 r., po ponad trzydziestu latach oczekiwania, druku retrospektywnej Bibliografii historii województwa Lubelskiego A. Wojtkowskiego ${ }^{80}$. Wydania bibliografii podjęli się pracownicy Zakładu Nauk Pomocniczych Historii i Bibliotekoznawstwa UMCS. Zestawia ona piśmiennictwo dotyczące dziejów województwa lubelskiego od najdawniejszych czasów do połowy 1944 r., które wydano do 1960 r. Dzieło to ma fundamentalne znaczenie dla historiografii lubelskiej. Bowiem

(...) daje należytą i pełną orientację w piśmiennictwie dotyczącym historii Lubelskiego do 1944 r. i wypełnia dotkliwą lukę w historiografii lubelskiej. (...)

${ }^{78}$ P. Dymmel, Z. Jakóbczak, Bibliografia publikacji pracowników Archiwum Państwowego w Lublinie 1918-2008, Lublin 2008.

${ }^{79}$ J. Plewko, Kronika 30-lecia Instytutu Badań nad Polonia i Duszpasterstwem Polonijnym Katolickiego Uniwersytetu Lubelskiego 1972-2002, Lublin 2002, s. 177-196.

${ }^{80}$ A. Wojtkowski, Bibliografia historii województwa lubelskiego, wydały M. Juda, A. Matczuk przy współpracy A. Znajomskiego, Lublin 2000. 
Jej wartość polega również na tym, że w dziejach bibliografii polskiej jest to druga, po bibliografii Wielkopolski, próba całościowego ujęcia historiografii regionu ${ }^{81}$.

Przybliżając dorobek lubelskich uczonych w zakresie bibliografii historycznych, nie sposób pominąc Bibliografii historii sztuki dawnego województwa lubelskiego za lata 1965-2000 (Lublin 2008), przygotowanej przez badacza dziejów sztuki Lechosława Lameńskiego z KUL. Jest ona bezpośrednią kontynuacją Bibliografii historii sztuki województwa lubelskiego za lata 1944-1964 Jerzego Kowalczyka ${ }^{82}$. Wydany spis jest przydatny zwłaszcza dla badaczy dziejów sztuki, bowiem mogą w nim znaleźć bardzo szeroką gamę materiałów bez względu na język publikacji i miejsce ich wydania. Wagę i znaczenie Bibliografii doceniła krytyka, która uznała dzieło za ,(...) pozycję ważną i wielce przydatną w studiach nad dziejami sztuki lubelskiej"83.

Nie mniej istotnym osiągnięciem było wydanie Bibliografii historii lubelskiego sportu (Lublin 2013), autorstwa historyków Dariusza Słapka i Ewy Zielińskiej, przygotowanej w Lubelskim Centrum Dokumentacji Historii Sportu funkcjonującym przy UMCS. Jest to pionierskie opracowanie nie tylko na gruncie lubelskim, ale też ogólnopolskim. Praca stanowi niezastąpione źródło informacji do opracowania monografii historii lubelskiego sportu ${ }^{84}$.

O dwa kolejne spisy bibliograficzne wzbogacił się dorobek lubelskich archeologów. W 1997 r. ukazała się Bibliografia archeologii Lubelszczyzny (Polski środkowowschodniej) za lata 1986-1995, przygotowana przez B. Bargieł ${ }^{85}$, będąca chronologiczną kontynuacją wspomnianej już bibliografii za lata 1971-1985.

Z kolei w 2003 r. wydano Materiaty do bibliografii prasowej archeologii w Masłomęczu, zgromadzone przez członków Koła Naukowego Archeologów Studentów UMCS, przygotowane do druku w opracowaniu redakcyjnym J. Gurby $^{86}$. W bibliografii zarejestrowano artykuły prasowe z lat 1977-2001, odnoszace się do badań archeologicznych w Masłomęczu.

Postępującemu rozwojowi charakteryzowanych bibliografii towarzyszyło zaniechanie niektórych wcześniejszych inicjatyw. W 1994 roku przestały ukazywać się Materiaty do bibliografii historycznej Lubelszczyzny. Ostatnie zestawienie opracowane przez B. Nowak obejmuje lata 1990-1992. Zaprzestanie publikowania bibliografii było spowodowane zawieszeniem wydawania „Rocznika Lubel-

${ }^{81}$ Matczuk: Rozwój bibliografii, s. 546-547.

${ }^{82}$ J. Kowalczyk, Bibliografii historii sztuki województwa lubelskiego za lata 1944-1964, „Biuletyn Historii Sztuki”, 27 (1965) nr 2, s. 116-134.

${ }^{83}$ L. Lameński, Bibliografii historii sztuki dawnego województwa lubelskiego za lata 19652000, Lublin 2008. Rec.: A. Matczuk, „Folia Bibliologica”, 52 (2010) s. 178.

${ }^{84}$ D. Słapek, E. Zielińska, Bibliografia historii lubelskiego sportu, Lublin 2013. Rec.: A. Matczuk, „Rocznik Lubelski”, 42 (2016) s. 282.

${ }^{85}$ B. Bargieł, Bibliografia archeologii Lubelszczyzny (Polski środkowowschodniej) za lata 19861995 z uzupetnieniami z lat poprzednich, „Archeologia Polski Środkowowschodniej”, 2 (1997) s. 341365.

${ }^{86}$ Dwadzieścia pięć lat archeologii w Masłomęczu. Materiaty do bibliografii prasowej archeologii w Mastomęczu, red. J. Gurba, Lublin 2003. 
skiego". Po reaktywacji periodyku w 2009 r. nie powrócono już do publikowania na jego łamach tej istotnej bibliografii, pomocnej w badaniach nad przeszłością regionu lubelskiego.

Oprócz bibliografii dziedzinowych regionalnych w środowisku lubelskim uprawiano także bibliografie zagadnieniowe o charakterze ogólnopolskim. Bardzo dużym sukcesem w tym względzie było wydanie w 1992 r. przez Wydawnictwo UMCS pracy socjologa Józefa Styka pt. Problematyka spoleczna wsi w piśmiennictwie polskim 1901-1988. Bibliografia. To obszerne dzieło, liczące 590 stron i zestawiające 11.000 opisów, zawiera niemal kompletny wykaz publikacji z zakresu socjologii wsi za prawie 90 lat XX w., w tym również opracowania dotyczące problematyki społecznej wsi, powstałe na polu innych dyscyplin naukowych. Dzięki szerokim kryteriom doboru materiału i rzetelnemu opracowaniu Bibliografia nie tylko wypełnia dotkliwą lukę w całościowej rejestracji piśmiennictwa $\mathrm{z}$ zakresu socjologii wsi, ale też stanowi funkcjonalną pomoc warsztatową dla badaczy zajmujących się wiejską problematyką społeczną. Ponadto jak słusznie zauważył recenzent „,(..) dzieła tego rodzaju mimo upływu lat nie tracą na wartości" $"$ 77.

Bibliografią zagadnieniową powstałą w omawianym okresie jest również Bibliografia edytorstwa źródet historycznych $w$ Polsce P. Dymmela z UMCS ${ }^{88}$. Praca ukazała się nakładem wydawnictwa tej uczelni jako jedyny dotychczas tom serii „Bibliografia Nauk Pomocniczych Historii”. Gromadzi ona piśmiennictwo z zakresu edytorstwa historycznego, a w szczególności dotyczące sztuki edytorskiej, dziejów edytorstwa, krytyki tekstu, metodyki i techniki wydawniczej, bez względu na język publikacji i miejsce ich wydania. Jako pierwsze tego typu zestawienie na gruncie polskim jest niewątpliwie ważnym narzędziem w warsztacie badaczy zajmujących się edytorstwem historycznym i innymi dyscyplinami nauk pomocniczymi historii.

Intensywny rozwój prac z historii literatury polskiej, mający miejsce w ostatnich kilkunastu latach, dał asumpt do stworzenia Bibliografii edycji i studiów o literaturze polskiego renesansu i baroku 1995-2009, przygotowanej w Instytucie Filologii Polskiej UMCS ${ }^{89}$. Uwzględnia ona wyłącznie publikacje naukowe dotyczące polskiej literatury renesansowej i barokowej oraz edycje dzieł autorów polskich z okresu odrodzenia i baroku.

Do niezmiernie wartościowych osiągnięć lubelskiego środowiska naukowego należy również Bibliografia schematyzmów zakonów męskich na ziemiach dawnej Rzeczypospolitej z lat 1718-1918 (Lublin 2016) autorstwa Edyty Chomentow-

${ }^{87}$ J. Styk, Problematyka społeczna wsi w piśmiennictwie polskim 1901-1988. Bibliografia, Lublin 1992. Rec.: K. Korab, „Roczniki Socjologii Wsi”, 26 (1998) s. 253.

${ }^{88}$ P. Dymmel, Bibliografia edytorstwa źródet historycznych w Polsce. Historia - krytyka tekstu - metodyka i technika wydawnicza, Lublin 2001. Rec.: A. Bartoszewicz, „Studia Źródłoznawcze”, 40 (2000), s. 247-250; I. H[lavaček], „Český Časopis Historický”, 100 (2002) č. 1, s. 152-153.

${ }^{89}$ Bibliografia edycji i studiów o literaturze polskiego renesansu i baroku 1995-2009, oprac. T. Lawenda przy współudziale P. Ciechana, M. Rybak, red. D. Chemperek, Warszawa 2011. Jest to kontynuacja bibliografii noszącej tytuł Barok. (Studia 1965-1995) (Warszawa 1996) przygotowanej w środowisku warszawskim przez A. Pawlak i M. Strykowską pod red. nauk. A. Nowickiej-Jeżowej. 
skiej z Ośrodka Badań nad Geografią Historyczną Kościoła w Polsce KUL. Dzieło opracowane w wersji dwujęzycznej (polsko-angielskiej) stanowi niezastąpioną pomoc $\mathrm{w}$ warsztacie naukowym uczonych polskich i zagranicznych zajmujących się dziejami Kościoła.

$\mathrm{Z}$ innych prac bibliograficznych o charakterze zagadnieniowym, na uwagę zasługuje retrospektywna Polska bibliografia briologiczna autorstwa Kazimierza Karczmarza i Mirosława Blocha ${ }^{90}$, pracowników Zakładu Systematyki Roślin UMCS. Prace nad przygotowaniem bibliografii podjęto z inicjatywy K. Karczmarza, twórcy lubelskiego ośrodka briologicznego, członka komitetu redakcyjnego serii „Bibliografie Botaniczne PAN”, którego ambicją była popularyzacja wiedzy briologicznej w środowisku naukowym i szkolnym. Dotychczas ukazał się tom pierwszy obejmujący lata 1786-1986. Wymienić również należy Bibliografię metodologicznych problemów andragogiki $i^{91}$, opracowaną przez Mieczysława Marczuka i Andrzeja Pikora z Instytutu Pedagogiki UMCS.

W omawianym okresie następował także dalszy rozwój bibliografii zawartości czasopism. W efekcie pracy ks. S. Librowskiego i Artura Hamryszczaka o kolejne trzy spisy zawartości wzbogaciły się „Archiwa, Biblioteki i Muzea Kościelne"92. Jak już wspomniano, A. Matczuk opracowała spis zawartości „Notatnika Janowieckiego". Natomiast Henryk Bałabuch przygotował bibliografię prac historycznych opublikowanych na łamach sekcji F „Annales UMCS" ${ }^{93}$. Okazją do jej opublikowania stało się wydanie jubileuszowego, 50. tomu czasopisma. Dzięki przyjętym zasadom doboru materiału udało się autorowi nakreślić ogólny obraz periodyku, preferującego przez cały okres swojego istnienia artykuły i wyniki badań z zakresu dziejów Polski i historii powszechnej. Podobny charakter ma bibliografia stworzona przez ks. Zenona Uchnasta i Małgorzatę Biegajło z KUL. Z tą tylko różnicą, że prezentuje ona prace psychologiczne ogłoszone na łamach „Roczników Filozoficznych"94. Jej wydanie wiąże się z powstaniem „Roczników Psychologicznych” (1998), które wyodrębniły się z zeszytów psychologicznych wydawanych w ramach „Roczników Filozoficznych”. Jubileusz 20. lecia istnienia „Zeszytów Naukowych Katolickiego Uniwersytetu Lubelskiego" stał się dobrą okazją do przygotowania bibliografii zawartości tego periodyku

${ }^{90}$ K. Karczmarz, M. Bloch, Polska bibliografia briologiczna, t. 1, (1786-1986), Lublin 1994.

${ }^{91}$ M. Marczuk, A. Pikor, Bibliografia metodologicznych problemów andragogiki, w: Problemy i dylematy andragogiki. Praca zbiorowa, red. M. Marczuk, Lublin 1994, s. 213-252.

${ }^{92}$ S. Librowski, Bibliografia zawartości czasopisma Archiwa, Biblioteki i Muzea Kościelne. Tomy 51-60, ABMK, 60 (1991) s. 586-592; A. Hamryszczak, Bibliografia zawartości czasopisma Archiwa, Biblioteki i Muzea Kościelne. Tomy 61-81, ABMK, 82 (2004), s. 5-30; A. Hamryszczak, Bibliografia zawartości czasopisma Archiwa, Biblioteki i Muzea Kościelne. Tomy 1-100, ABMK, 101 (2014) s. 5-91.

${ }^{93}$ Bibliografia prac historycznych wydanych w 50 tomach ,Annales UMCS, sectio $F$ w latach 1946-1995, oprac. H. Bałabuch, „Annales UMCS. Sect. F”, 50 (1995) s. 11-30.

${ }^{94}$ Wykaz rozpraw z zakresu psychologii opublikowanych $w$ Rocznikach Filozoficznych, Z. 4: Psychologia w latach 1957-1997, oprac. Z. Uchnast, M. Biegajło, „Roczniki Psychologiczne”, 1 (1998) s. 206-223. 
za lata 1978-1997, opracowanej przez Jakuba A. Malika. ${ }^{95}$ Jest to kontynuacją wcześniejszego spisu zestawionego przez Kazimierę Wiśniowską, obejmującego okres 1958-1977. Zestawienie odzwierciedla wkład poszczególnych jednostek uczelni w publikowanie artykułów na łamach „Zeszytów Naukowych”. Swojej bibliografii doczekał się również kwartalnik „Ethos”, będący organem Instytutu Jana Pawła II KUL ${ }^{96}$.

Nad bibliografią zawartości „Zeszytów Wojnickich” pracował do ostatnich dni swojego życia, wspomniany już wcześniej, J. Szymański. Wypracował on koncepcję całego zestawienia, rozpisał większość zeszytów czasopisma, ale nie zdołał już sfinalizować druku bibliografii ${ }^{97}$.

Lubelskie środowisko naukowe podejmowało także inicjatywy w zakresie bibliografii lokalnych. Współpraca Instytutu Bibliotekoznawstwa i Informacji Naukowej UMCS z Urzędem Miasta Świdnik przyniosła retrospektywną Bibliografię miasta Świdnika do roku 2003, opracowaną pod redakcją A. Matczuk i Artura Znajomskiego ${ }^{98}$. Dokumentuje ona piśmiennictwo dotyczące miasta za okres 50. lat jego istnienia. A. Matczuk jest również współautorką Bibliografii miasta Stalowa Wola za lata 1989-201099.

Opracowaniem bibliografii lokalnej zajmował się również słowianoznawca Feliks Czyżewski. Zestawił on Bibliografie prac dotyczacych gminy Wola Uhru$s k a^{100}$. Podobnie jak bibliografia Świdnika i Stalowej Woli ma ona charakter przedmiotowy.

Lubelscy uczeni zajmują się także krzewieniem kultury bibliograficznej wśród studentów. Wiodącą rolę odgrywał na tym polu nieistniejący już Zakład Nauk Pomocniczych Historii i Bibliotekoznawstwa, a obecnie zadanie to realizuje Instytut Informacji Naukowej i Bibliotekoznawstwa UMCS. W ramach studiów stacjonarnych, zaocznych i podyplomowych na kierunku bibliotekoznawstwo $\mathrm{i}$ informacja naukowa, realizowano obligatoryjne zajęcia $\mathrm{z}$ bibliografii $\mathrm{w}$ formie wykładów i ćwiczeń oraz prowadzono seminaria z zakresu bibliografii. Prowadzili je na przestrzeni lat kolejno: Andrzej Skrzypczak, A. Matczuk i A. Znajomski, którzy zawodowo zajmują się badaniami i praktyką bibliograficzną. Na seminariach przygotowywano prace teoretyczne $\mathrm{z}$ zakresu bibliografii oraz tworzono spisy bibliograficzne. Powstawały bibliografie osobowe, zawartości czasopism, regionalne, lokalne oraz zagadnieniowe. Większość z nich pozostaje w formie

${ }^{95}$ Bibliografia zawartości „,Zeszytów Naukowych Katolickiego Uniwersytetu Lubelskiego” za lata 1978-1997, zest. J. A. Malik, „Zeszyty Naukowe Katolickiego Uniwersytetu Lubelskiego”, 43 (2000) s. 149-205.

${ }^{96}$ Ethos. Bibliografia zawartości 1988-2000, oprac. M. Filipiak, Lublin 2001.

${ }^{97}$ Informacje od autorów artykułu.

${ }^{98}$ K. Waszczeniuk, A. Sztorc, Bibliografia miasta Świdnika do roku 2003, oprac. pod kier. A. Matczuk i A. Znajomskiego, Świdnik 2006.

${ }^{99}$ B. Burdzy, A. Matczuk, Bibliografii miasta Stalowa Wola za lata 1989-2010, Stalowa Wola 2012.

${ }^{100}$ F. Czyżewski, Bibliografia prac dotyczacych gminy Wola Uhruska (wybór), w: Gmina Wola Uhruska na tle Euroregionu Bug. Język i kultura, red. F. Czyżewski, Wola Uhruska 2003, s. 245254. 
maszynopisów, ale niektóre zostały opublikowane. Wśród nich są znane już bibliografie Świdnika i Stalowej Woli, pierwsza przygotowana została przez studentów III roku jako praca zaliczeniowa, a druga powstała jako praca dyplomowa na studiach podyplomowych z zakresu informacji naukowej i bibliotekoznawstwa. Publikacji doczekała się także inna praca dyplomowa, a mianowicie bibliografia osobowa podmiotowo-przedmiotowa lekarza, historyka i bibliofila Zygmunta Klukowskiego ${ }^{101}$.

Inicjatorami szeregu spisów bibliograficznych byli też pracownicy Instytutu Filologii Polskiej UMCS, J. Bartmiński i S. Niebrzegowska-Bartmińska, którzy prowadzili seminaria magisterskie na kierunku bibliotekoznawstwo i informacja naukowa. J. Bartmiński podczas zajęć seminaryjnych zaszczepił pasją bibliograficzną niektórych swoich magistrantów. Wśród nich są znani w środowisku bibliologicznym badacze bibliografii, jak np. Jarosław Pacek, pełniący obecnie obowiązki kierownika Instytutu Bibliograficznego w Bibliotece Narodowej w Warszawie oraz osoby zajmujące się praktyką bibliograficzną. Wychowanką J. Bartmińskiego jest wymieniana już B. Maksymiuk-Pacek, która ma na swoim koncie kilka ważnych opracowań bibliograficznych. Należy również podkreślić, że druku doczekała się część prac magisterskich przygotowanych pod kierunkiem J. Bartmińskiego, co jest dowodem ich wartości i znaczenia ${ }^{102}$.

$\mathrm{Z}$ innych ogłoszonych drukiem prac magisterskich na uwagę zasługuje $\mathrm{Bi}$ bliografia bibliografii językoznawstwa polskiego (Lublin 2000) Eweliny Niemkiewicz, przygotowana w Katedrze Języka Polskiego KUL pod opieką Zenona Leszczyńskiego.

Opublikowana również została, z tym że w formie elektronicznej, praca magisterska Adama Orlika zatytułowana Bibliografia zawartości „,Twórczości Ludowej" za lata 1986-2000 powstała w Instytucie Kulturoznawstwa UMCS pod kierunkiem Jana Adamowskiego.

Rozwój kultury bibliograficznej nie byłby możliwy bez wydawców. Ciężar publikowania bibliografii biorą na siebie na ogół wydawnictwa poszczególnych uczelni lubelskich. Niekwestionowanymi liderami są w tym względzie Wydawnictwo UMCS i Towarzystwo Naukowe KUL. Daje się zauważyć, że instytucje te darzą bibliografie szczególną estymą, choć ich wydawanie przeważnie jest niedochodowe. Mimo to obydwa wydawnictwa ogłosiły drukiem cały szereg bibliografii, niejednokrotnie w postaci obszernych tomów i nadal je publikują.

Postępujący rozwój technologii informacyjnej sprawił, że środowisko lubelskie przygotowuje bibliografie nie tylko w formie drukowanej, ale też tworzy je w wersji elektronicznej, przez co dostęp do nich i zasięg ich oddziaływania jest praktycznie powszechny. Postać online ma wspomniana Bibliografia zawartości „,Twórczości Ludowej”. Również czasopismo „Excerpta Veterinaria” od rocznika 47 (2008) wychodzi wyłącznie w formie elektronicznej. Wersje tradycyjną

${ }^{101}$ D. R. Kawałko, Zygmunt Klukowski 1885-1959. Bibliografia podmiotowo-przedmiotowa (do roku 2008), oprac. pod kier. A. Matczuk, Szczebrzeszyn 2009.

102 Zob. A. Boguta, Bibliografia analityczna „Czerwonej Serii” 1981-2008. Tomy 1-25, oprac. pod kier. A. Matczuk, Lublin 2010 oraz Etnolingwistyka. Bibliografia adnotowana 1988-2008, oprac. Ł. Tomczak, red. J. Bartmiński, S. Wasiuta, Lublin 2010. 
i elektroniczną mają natomiast dwa inne spisy, tj. Bibliografia historii lubelskiego sportu oraz Bibliografia map i planów opracowanych w Instytucie Geografii Historycznej Kościoła w Polsce. Pierwsze zestawienie jest udostępnione na stronie Lubelskiego Centrum Dokumentacji Historii Sportu, a drugie znajduje się na stronie internetową Ośrodka Badań nad Geografią Historyczną Kościoła w Polsce KUL. Publikowanie bibliografii online jest nowym trendem w upowszechnianiu kultury bibliograficznej i z całą pewnością ten nurt wydawniczy będzie się rozwijat.

Podsumowując trzeba powiedzieć, że działalność bibliograficzna dla większości uczonych lubelskich była wynikiem okazjonalnych sytuacji i miała charakter okolicznościowy. Stanowiła przeważnie epizod w ich naukowej biografii. Po opublikowaniu swoich prac bibliograficznych, uczeni najczęściej już nie powracali do tego typu działań.

Należy stwierdzić, że lubelskie środowisko naukowe cechowało się rozległością zainteresowań bibliograficznych, poczynając od bibliografii ogólnodziedzinowej i dziedzinowej regionalnej, poprzez bibliografię zagadnieniową, osobową, zespołów osobowych, lokalną, zawartości czasopism, kończąc na zestawieniach prac dyplomowych.

Do rozwoju kultury bibliograficznej w lubelskim środowisku naukowym przyczynili się w głównej mierze uczeni związani z Uniwersytetem Marii Curie-Skłodowskiej i Katolickim Uniwersytetem Lubelskim Jana Pawła II. Pierwsi zasłużyli się przede wszystkim jako autorzy bibliografii osobowych, zagadnieniowych i dziedzinowych regionalnych, będących podstawą badań regionalnych. Natomiast pracownicy KUL preferowali bibliografie dziedzinowe oraz bibliografie zespołów osobowych, dokumentujące i propagujące dorobek naukowy poszczególnych jednostek uczelni.

Warto podkreślić także fakt, że twórczość bibliograficzna uczonych lubelskich miała nierzadko charakter pionierski i niejednokrotnie przekraczała ramy regionu, stając się trwałym dorobkiem bibliografii ogólnopolskiej.

\section{BIBLIOGRAFIA}

\section{Opracowania}

Araszkiewicz Feliks, Zastugi Wiktora Hahna dla środowiska naukowego. (Przemówienie Feliksa Araszkiewicza), „Zeszyty Naukowe KUL”, 3 (1960) nr 1, s. 158-160.

Bartoszewicz Agnieszka, (rec.), Dymmel Piotr, Bibliografia edytorstwa źródet historycznych $w$ Polsce. Historia - krytyka tekstu - metodyka i technika wydawnicza, Lublin 2001, „Studia Źródłoznawcze”, 40 (2000), s. 247-250.

Bobrowska-Nowak Wanda, Profesor Józef Reutt (1907-1972), „Psychologia Wychowawcza”, 16 (1973), s. 530-531.

Czachowska Jadwiga, Loth Roman, Przewodnik polonisty. Bibliografie, biblioteki, muzea literackie, Wrocław 1989.

Drzewiecki Marcin, (rec.), Religia a literatura. Bibliografia. Prace polskie 1966-1969, oprac. M. Błońska, M. Józefacka, M. Kunowska-Porębna, Lublin 1972, „Bibliotekarz", (1973) nr 9, s. 282-284. 
Gajewski Leszek, (rec.), Pradzieje Lubelszczyzny w prasie lubelskiej. Bibliografia za lata 1960-1974, oprac. B. Bargieł [i in.], Lublin 1974, „Kwartalnik Historii Kultury Materialnej”, 24 (1975), s. 499-500.

Gardziel Zbigniew, (rec.), Morawski Jan, Nowak Jerzy, Bibliografia Lubelskiego Zagłębia Weglowego, Lublin 1977, „Przegląd Geologiczny”, (1978) nr 9, s. 564.

Garlicka Aleksandra, (rec.), Bibliografia katolickich czasopism religijnych w Polsce 19181944, oprac. i red. Z. Zieliński, Lublin 1981, „Kwartalnik Historii Prasy Polskiej”, 22 (1983) z. 2, s. 99-101.

Hadrian Ewa, Profesor Jerzy Starnawski (1922-2012) - historyk i badacz literatury polskiej, neolatynista, bibliograf, pedagog, edytor, erudyta, „Bibliotekarz Lubelski”, 55 (2012), s. 19-26.

Hamryszczak Artur, Bibliografia zawartości czasopisma Archiwa, Biblioteki i Muzea Kościelne. Tomy 1-100, „Archiwa Biblioteki i Muzea Kościelne”, 101 (2014) s. 5-91.

Hinkel Heinz, (rec.), Bieńkowski Ludomir, Flaga Jerzy, Sułowski Zygmunt, Cartographie historique de la Pologne. Bibliographie des cartes concernant les rapports religieux dans les annes 1851-1968. - Bibliographie de cartographie ecclesiastique, Leiden 1971, „Zeitschrift für Ostforschung», 23 (1974) H. 2, s. 320-321.

H[lavaček] I[van], (rec.), Dymmel Piotr, Bibliografia edytorstwa źródeł historycznych w Polsce. Historia - krytyka tekstu - metodyka i technika wydawnicza, Lublin 2001, „Český Ćasopis Historický”, 100 (2002) č. 1, s. 152-153.

Irzyk Zbigniew, (rec.), Religia a literatura. Bibliografia. Prace polskie 1966-1969, oprac. M. Błońska, M. Józefacka, M. Kunowska-Porębna, Lublin 1972, „Życie i Myśl”, (1973) nr 6, s. 141-142.

Korab Kazimierz, (rec.), Styk Józef, Problematyka społeczna wsi w piśmiennictwie polskim 1901-1988. Bibliografia, Lublin 1992, „Roczniki Socjologii Wsi”, 26 (1998) s. 253-256.

Korczak-Michalewski Serafin, (rec.), Margul Tadeusz, Międzynarodowa bibliografia religioznawstwa porównawczego w układzie działowym, Kraków 1984, „Nowe Książki", (1987) nr 2, s. 130.

Krzywicka Monika, Matczuk Alicja, Bibliografia w kręgu zainteresowań Hieronima Łopacińskiego, w: Hieronim Łopaciński epoka, ludzie, region. Materiały z konferencji naukowej. Lublin, 19-20 września 2006, red. Z. Bieleń, Lublin 2006, s. 127-142.

Kujawski Witold, Ks. Stanisław Librowski włocławski historyk i archiwista, ,Studia Włocławskie", 10 (2007), s. 65-77.

Librowski Stanisław, Bibliografie osobowe pracowników nauki oraz ich przygotowanie, „Archiwa, Biblioteki i Muzea Kościelne”, 36 (1978), s. 6-16.

Markowski Adam, (rec.), Religia a literatura. Bibliografia. Prace polskie 1966-1969, oprac. M. Błońska, M. Józefacka, M. Kunowska-Porębna, Lublin 1972, „Tygodnik Powszechny", (1973) nr 15, s. 6.

Matczuk Alicja, (rec.), Lameński Lechosław, Bibliografii historii sztuki dawnego województwa lubelskiego za lata 1965-2000, Lublin 2008, „Folia Bibliologica”, 52 (2010), s. 173-178.

Matczuk Alicja, Lublin i Lubelszczyzna w życiu i twórczości wybitnych polskich bibliografów, „Bibliotekarz Lubelski”, 47 (2004), s. 108-110.

Matczuk Alicja, ,,Nowości lubelskie”-przyczynek do dziejów humoru bibliograficznego w Polsce, ,Folia Bibliologica”, 52 (2010), s. 9-26.

Matczuk Alicja, Polskie bibliografie nauk humanistycznych i społecznych. Historia i metodyka, Lublin 2014.

Matczuk Alicja, Rozwój bibliografii ziemi lubelskiej, w: Lublin a książka, red. A. Krawczyk, E. Józefowicz-Wisińska, Lublin 2004, s. 531-557.

Matczuk Alicja, (rec.), Słapek Dariusz, Zielińska Ewa, Bibliografia historii lubelskiego sportu, Lublin 2013, „Rocznik Lubelski”, 42 (2016), s. 281-286. 
Matczuk Alicja, Wprowadzenie do bibliografii, w: A. Wojtkowski, Bibliografia historii województwa lubelskiego, wydały M. Juda, A. Matczuk przy współpracy A. Znajomskiego, Lublin 2000, s. 21-30.

Meyer G.F. (rec.), Kaczmarek Leon, Dobrzański Zdzisław, Kania Józef, Polska bibliografia logopedyczna, Lublin 1965, „Zeitschrift fur Phonetik, Sprachwissenschft und Kommunikationsforschung", 24 (1971) H. 5, s. 445-446.

Nir Roman, (rec.), Bieńkowski Ludomir, Flaga Jerzy, Sułowski Zygmunt, Cartographie historique de la Pologne. Bibliographie des cartes concernant les rapports religieux dans les annes 1851-1968. - Bibliographie de cartographie ecclesiastique, Leiden 1971, „Kwartalnik Historyczny”, 81 (1974) nr 1, s. 220-224.

Rayss Jan, Profesor Andrzej Waksmundzki, „Orbital”, (1999) nr 3, s. 191-194.

Rzepka W.R, (rec.) Kaczmarek Leon, Dobrzański Zdzisław, Kania Józef, Polska bibliografia logopedyczna, Lublin 1965, „Biuletyn Fonograficzny”, 9 (1968), s. 132-135.

Stachyra J, (rec.), Kaczmarek Leon, Dobrzański Zdzisław, Kania Józef, Polska bibliografia logopedyczna, Lublin 1965, „Szkoła Specjalna”, 1967, nr 1, s. 88.

Trzydziestolecie pracy naukowej Tadeusza Margula, „Euhemer”, (1985) nr 2, s. 161-167.

Tyszkiewicz Teresa, (rec.), Religia a literatura. Bibliografia. Prace polskie 1966-1969, oprac. M. Błońska, M. Józefacka, M. Kunowska-Porębna, Lublin 1972, „Pamiętnik Literacki”, 64 (1973) z. 3, s. 341-343.

Wilk Wiesław, (rec.), Religia a literatura. Bibliografia. Prace polskie 1966-1969, oprac. M. Błońska, M. Józefacka, M. Kunowska-Porębna, Lublin 1972, „Ruch Biblijny i Liturgiczny", (1973) nr 4, s. 239-240.

Z. Br., (rec.), Kaczmarek Leon, Dobrzański Zdzisław, Kania Józef, Polska bibliografia logopedyczna, Lublin 1965, „Kwartalnik Historii Nauki i Techniki”, 12 (1967) z .1, s. $181-182$.

Znajomski Artur, Bibliografie zespołów osobowych - instytucji. Stan i potrzeby. W: Bibliografia. Teoria, praktyka, dydaktyka, red. J. Woźniak-Kasperek, M. Ochmański, Warszawa 2009, s. 117-129.

Znajomski Artur, Wiktor Hahn jako bibliograf lubelski, w: Lublin a książka, red. A. Krawczyk, E. Józefowicz-Wisińska, Lublin 2004, s. 609-624.

\section{Netografia}

http://www.hieronim.wbp.lublin.pl/ (dostęp: 8.06.2017).

\section{KULTURA BIBLIOGRAFICZNA LUBELSKIEGO ŚRODOWISKA NAUKOWEGO OD KOŃCA XIX WIEKU DO ROKU 2016}

\section{Streszczenie}

Początek kultury bibliograficznej lubelskiego środowiska naukowego datuje się na schyłek XIX w. i wiąże się z działalnością Hieronima Łopacińskiego. W 1891 roku wydał on omówienie bibliograficzne pt. Wydawnictwa periodyczne w Lublinie. Zainicjowany kierunek twórczy był kontynuowany w dwudziestoleciu międzywojennym, kiedy to, pod wpływem regionalizmu i rozwijających się badań naukowych, zaczęto ogłaszać ogólną bieżącą Bibliografię województwa lubelskiego autorstwa Wiktora Hahna oraz opublikowano pierwsze regionalne bibliografie dziedzinowe z zakresu historii i literatury. W latach dwudziestych prowadzono też prace nad pionierską, retrospektywną Bibliografia miasta Lublina, ale nie zostały one zakończone. 
Intensywny rozwój kultury bibliograficznej nastąpił w Lublinie po II wojnie światowej. Wraz z powstawaniem kolejnych uczelni wyższych, rozbudową ich infrastruktury badawczej i przyrostem kadry naukowej, lubelscy uczeni zaczęli podejmować szereg przedsięwzięć bibliograficznych. W sferze ich zainteresowania były bibliografie ogólnodziedzinowe i dziedzinowe regionalne, tworzono bibliografie zagadnieniowe, osobowe, zespołów osobowych, lokalne, zawartości czasopism oraz zestawienia prac dyplomowych.

Słowa kluczowe: kultura bibliograficzna; lubelskie środowisko naukowe; XIX-XXI wiek

\title{
THE BIBLIOGRAPHIC CULTURE OF THE LUBLIN SCHOLARLY COMMUNITY FROM THE END OF THE 19TH CENTURY TO 2016
}

\begin{abstract}
Summary
The beginning of the Lublin bibliographic culture of the Lublin scholarly community dates back to the late 19th century and is connected with Hieronim Łopaciński. In 1891 he published the bibliographic review entitled 'Periodical Publications in Lublin'. This initiative was continued in the interwar period, when, under the influence of regionalism and the development of research, the general current 'Bibliography of the Lublin Province' prepared by Wiktor Hahn was published. In addition, the first regional bibliographies in the field of history and literature were released. In the 1920s the pioneer, retrospective 'Bibliography of Lublin' was being prepared, but the work was not completed.

The work on bibliography intensified in Lublin after World War II. With the emergence of new universities, the development of research infrastructure and the increase in the research personnel, the Lublin scholars began a number of bibliographic projects. They were interested in general, special and regional bibliographies. They prepared subject, author(s) and local bibliographies, the bibliographies of the magazine contents as well as the lists of dissertations.
\end{abstract}

Keywords: bibliographic culture; the Lublin scholarly community; 19th-21st centuries 